\title{
Intrastate Conflict and Natural Resources: \\ A Question of Geology?
}

\author{
Christina A. Boyes \\ University of Colorado Boulder \\ Christina.Boyes@colorado.edu
}

\section{NOTE: This is a conference paper. Please do not cite or circulate without the author's written permission.}

How do natural resources deposits affect how armed actors behave in intrastate conflict? I argue that armed actors use a strategic calculus which includes resource extraction complexity when determining which natural resource deposits to fight over. Although often unaddressed, the extraction process directly affects the 'lootability' of a resource as well as the relationship of local, state, and international governments and multinational corporations with the actors that control natural resource deposits. I argue that sedimentary deposits, which pose minor technical complexity and human capital, but are more difficult to exploit than surficial deposits and easier to exploit than igneous or metamorphic deposits, are the most likely sites of violence in intrastate conflict. Using this novel conceptualization of natural resources by geological characteristics, I find support for this hypothesis at the global level using data from the UCDP Georeferenced Event Dataset and the United States Geological Survey's Mineral Resource Online Spatial Data. I find further support for the visual analysis in the Democratic Republic of the Congo via an examination of the common average points in polygons (administrative unit) for total violence and deposit type using the same data sources.

Keywords: natural resources, intrastate conflict, spatial data, armed actors, conflict location

How does the variance in natural resource extraction requirements affect where armed actors will fight over natural resources? While the impact of natural resources on civil conflict has been an active area of research in political science studies of intrastate conflict since Collier and Hoeffler's seminal work introduced the idea of natural resources ${ }^{1}$ as a potential cause of intrastate conflict onset, this basic question remains unanswered. In this paper, I address the current discussion and conceptualization of natural resources by intrastate conflict scholars. I ask what we can add to the discussion of natural resources in the intrastate literature and how we can clarify existing inconsistencies surrounding where

\footnotetext{
${ }^{1}$ Described as primary commodity exports.
} 
armed actors fight over natural resource deposits. I begin with a discussion of natural resources in civil conflict and problems with the current discussion - particularly the focus on natural resource lootability - then address how we can overcome the problems in the existing discussion by considering the importance of human capital and the technical requirements of natural resource extraction. This broad background of the role of natural resources in intrastate conflict is followed by a more focused assessment of how natural resources are thought to affect intrastate conflict location.

The study of intrastate conflict began with a focus on causes such as relative deprivation (e.g. Gurr 1970), ethnic heterogeneity in identity conflicts, conflict contagion, and undemocratic neighbors (Sambanis 2001), or contentious politics and transnational social movements (Tarrow 2015 based on the works of Tilly 1975). Later approaches placed emphasis on economic factors that grew out of prior approaches, such as grievance and greed (e.g. Collier and Hoeffler 1998, 2004; Fearon and Laitin 2003; Humphreys and Weinstein 2008) which drew on Gurr's (1970) Why Men Rebel. The recognition that greed and grievance alone were insufficient led to emphasis on additional economic and social factors such as motivation and opportunity (e.g. Boix 2016) and international trade in natural resources (Davies 2000). Out of the seminal works of Collier and Hoeffler $(1998,2004)$ and Fearon and Laitin (2003), inquiries into the role of natural resources in conflict emerged. The research program initially arose from Collier and Hoeffler's (2004) finding that primary commodity exports are related to the onset of intrastate conflict and dissatisfaction with the proposed mechanisms explaining why.

A healthy body of scholarly work on the role of natural resources now argues that natural resources can provoke intrastate conflict onset, extend and exacerbate civil conflict by providing armed actors in civil conflict with fungible income, decrease rebel group reliance on local populations, and provide a territorial prize for states and rebel actors to fight over. Likewise, natural resources are thought to provoke slow economic growth, facilitate corruption, entrench autocrats, and lead to the phenomenon known as the 'resource curse', whereby poor governance leads to socioeconomic grievances that can spur or exacerbate civil conflict (Samset 2015).

Different aspects of natural resources have been examined by political scientists and political geographers alike as potentially explaining the role of natural resources in civil conflict. Natural resources have been classified as renewable or nonrenewable, point or diffuse, easy to smuggle, or lootable. Scholars have measured natural resources as a percent of GDP per capita, by their total export value, the size or value of the natural resource deposits, by the specific resource itself (e.g. oil, diamonds, etc.), the dependence of a state on its resource exports, and so on.

Regardless of how they are described, often implicit in the discussion of natural resources in civil conflict is the flawed assumption that extraction is relatively easy and requires little technical expertise or infrastructure. While the point or diffuse nature of natural resource deposits put forth by Auty (2001a, 2001b) and the secondary vs. primary nature of diamonds Lujala et al (2005) mention begin to discuss difficulties in extracting natural resources from a geographical perspective, they do not address the need for human capital and technical infrastructure to complete this process or to process raw materials for sale as resource commodities. More prevalent conceptualizations of natural resources 
as 'smugglable' or 'lootable' have dominated the field following LeBillon's (2001) criticism of prior descriptors, but are inconsistently defined across studies. Furthermore, the existing conflict literature ignores the role of human capital in determining how actors extract natural resources. The extraction process directly affects the 'lootability' of a resource, but also impacts the relationship of local, state, and international governments and multinational corporations with the actors that control natural resource deposits and even the propensity for conflict onset.

The current challenge for researchers examining how natural resources affect intrastate conflict is to assess what lessons can we draw from the existing literature and how we might better approach the study of natural resources in conflict so as to resolve some of the inconsistencies encountered. To date, the lack of consistent classifications of natural resources in the conflict literature has led to mixed empirical findings regarding the importance of natural resources to conflict. In order to accurately assess the role of natural resources to conflict, we must begin with a technical understanding of natural resources and the human capital and technical infrastructure needed to develop, exploit, and process them for sale as commodities.

Following the seminal works of Collier and Hoeffler (1998, 2004), debates over which resources mattered to conflict and how sprung up in the literature, as did arguments challenging the role of natural resources as important to conflict. The large- $\mathrm{N}$ intrastate conflict literature places a near-myopic focus on specific resources, namely oil and diamonds. These resources have received disproportionately high attention in the literature, addressed from multiple angles and via myriad conceptualizations and operationalizations. Notably, most of the econometric research into natural resources in conflict has centered on the roles of these two resources (e.g. Lujala 2005, 2009, 2010; Ross 2012), yet qualitative accounts support the importance of other resources in conflict, including through artisanal gold mining and the trafficking of illegal drug crops (e.g. Rettberg and Ortiz-Riomalo 2016, Verbrugge 2015). Despite numerous theoretical arguments as to why and how natural resources affect conflict however, few attempts have been made to examine their overall impact on conflict and those that have (e.g. Collier and Hoeffler 1998) use crude conceptualizations that fail to capture the complexity of the socio-ecological system at work in intrastate conflicts involving natural resources.

To understand how and when natural resources affect intrastate conflict, we have to account for the technical knowledge and human capital required for their extraction. I take up this challenge by reconceptualizing natural resources using insights from the engineering and geological communities on the physical characteristics of natural resource deposits and the extent of human capital required to make use of natural resources. This new perspective on natural resources in conflict allows me to gain deeper insight into how natural resources are related to conflict location.

\section{Natural Resources in Civil Conflict}

Early studies placed a neo-malthusian focus on natural resource scarcity that was quickly substituted at the intrastate level with focus on resource abundance. The focus on plentiful resources and primary commodity exports led to discussions of natural resource lootability. The concept of lootability 
seemed intuitive; rebels could take fungible resources and run. As a concept however, lootability does not mean the same thing to everyone - not even to scholars studying it. I discuss the shortcomings with lootability in the existing discussions surrounding natural resources in conflict, and suggest how they might be addressed by accounting for human capital and technical capacity. The section closes with a discussion of key camps in the intrastate conflict literature surrounding natural resources' impact on conflict location, the puzzles that arise from comparing the findings in these camps and how we may resolve them.

Several scholars who assessed the state of the literature on natural resources in intrastate conflict express concerns regarding the varied ways in which natural resources are described and measured (e.g.Koubi et al 2013, Mildner et al 2011, Nillesen and Bulte 2014). The location of natural resources and complexity of their extraction process are theoretically relevant, yet only a few resources have been examined with these considerations in mind, and only in a handful of studies (e.g. Lujala 2007, 2010). The study design for several of the studies that do pay some heed to the complexity of extraction are microlevel or limited in the types of resources they examine, making it difficult to scale up and derive cross-national or cross-resource implications from their findings (e.g. Bellows and Miguel 2009, Sorens 2011).

The modern study of natural resources as related to conflict began with the work of neo-Malthusian scholars who assumed a relationship between resource scarcity and conflict onset (e.g. Bachler et al 19961 Homer-Dixon 1994, 1999), but has refocused on the role of more abundant resources in conflict (e.g. Collier and Hoeffler 1998). Despite theoretically interesting grounds, the neo-Malthusian argument has only found weak empirical support at the intrastate level, and is considered more likely at lower levels of conflict (Koubi et al 2013). Modern civil war scholars have found mixed, and yet seemingly strong, empirical evidence for the role of abundant resources in civil conflict. The conversation surrounding the role more abundant resources play in conflict began largely with the works of Collier and Hoeffler in the late 1990s and early 2000s, who discovered a relationship between primary commodity exports per capita and civil conflict (Collier and Hoeffler 1998, Koubi et al 2013, Samset 2015).

In 2003, Ross followed LeBillon (2001) in suggesting that the conceptualization of lootability is important. LeBillon (2001) did not place exclusive focus on lootability, he also considered value to weight ratios, as did Auty (2004). Ross (2003) introduces more nuance to the definition of lootability however, by arguing that lootable resources are those that are easily extractable and transportable by unskilled labor. Lack of conceptual consensus has led to mixed findings in the literature and some uses of lootability are problematic. For example, Ross (2003) and Welsch (2008) classify lootable resources differently; to Welsch (2008), agricultural resources are determinants of productivity, and not considered lootable resources. Welsch (2008) also lumps all subsoil assets as 'lootable', particularly mentioning bauxite, gold, diamonds, and oil. Ross (2003), however, conceptualizes oil, natural gas, and 'deepshaft' minerals as 'unlootable' resources, but drugs and alluvial gems and minerals as 'lootable'. Therefore, Ross (2003) and Welsch (2008) stand as near polar opposites in their conceptualization of natural resources. While drugs are an agricultural resource that can be relatively 
easy to obtain for a rebel group if cultivation is underway or territory has been consolidated, diamonds occur in multiple types of deposits. Diamonds in a pegmatite igneous deposit are very difficult to extract and require specialized equipment and human capital. Alluvial diamonds can be gathered off the ground by unskilled workers, however. It is no surprise, therefore, that scholars employing the concept of 'lootable' resources have difficulty agreeing which resources are 'lootable' and the lack of consistent measurement for 'lootable' resources in the field poses obvious problems for scholars relying on this concept to draw conclusions regarding the impact of natural resources on conflict.

Often, lootability may seem to cross with human capital to an extent. Yet, the literature on lootability does not take sufficiently into account the fact that different types of natural resource deposits, even of the same type of resource, require varied levels of technical expertise. While a simple measurement of lootability could explain the role of alluvial diamonds, coca, and opium in lengthening the duration of civil conflict, it cannot explain why alluvial diamonds (secondary diamonds) would have a contrary association with conflict to kimberlite diamonds (primary diamonds), which are harder to extract and require greater technical expertise. Much of Ross's work (2003, 2004, 2006) and Lujala et al (2005) begin to address this issue, but only examine a few key resource types (namely, diamonds and oil) and a rough description of their site characteristics. Their work does not attempt to tease out and measure the mechanisms that make these site characteristics particularly relevant (i.e. the human capital and the technical capacity required for resource extraction).

More complex measurements that still cling to lootability, such as the disaggregated measures for natural resource exploitation behavior described in the Rebel Contraband Dataset (Conrad et al 2018, Walsh et al 2018), are incomplete for several reasons.

First, by failing to account for the role of human capital, existing approaches to natural resources in intrastate conflict leave the arena for political action absent from the discussion. Human capital is different from labor ${ }^{2}$; in developing contexts that are more prone to conflict, human capital itself is a scarce and highly-valued resource. Natural resources should be understood not only by their type or geographic distribution, but also by their human capital and technical requirements for extraction.

Second, the discussion of lootability implicitly assumes that natural resources are valuable to rebels as a source of funding, but does not address the intrinsic value armed actors may see in controlling the natural resource deposits and consolidating territory surrounding them. Lootable resources, by definition, are those found in surficial deposits and in relatively finished forms. They exclude resources such as artisanal gold which require secondary processing in order to be of value. Yet, we see qualitative accounts of conflict wherein resources such as artisanal gold do matter for conflict (Rettberg and Ortiz-Riomalo 2016).

Third, armed rebel actors arise in contexts that possess social traits conducive to their successful formation (Larson and Lewis 2018), although natural resources may play a role in

\footnotetext{
${ }^{2}$ Human capital refers to highly-skilled and often, highly-educated, workers. Labor, on the other hand, refers to unskilled labor.
} 
determining their eventual success (Weinstein 2007). Measuring the importance of natural resources to intrastate conflict as a function of human capital would allow scholars to examine questions surrounding rebel group strategies towards target selection and territorial consolidation, as well as more typical outcomes such as intrastate conflict onset.

Finally, the behavior of state and paramilitary actors towards natural resource deposits cannot be explained by 'lootability' despite often mirroring the behavior of armed rebel actors. These state and state-authorized groups face the same calculations that armed actors do when natural resources are involved in conflict. They engage in looting, take control of deposits, and engage with local communities that extract resources in similar ways, and hence should not be overlooked when we assess the role of natural resources in conflict. Yet, for a legitimate armed actor, 'lootability' is of little concern. The state may sanction control or permit resource expropriation in order to fund conflict, making it easier for state forces and paramilitaries to take control of deposits, but they still face a similar decision calculus to armed actors when evaluating which deposits to extract from, whether or not to (re)consolidate territory, and which natural resource deposits are best to pursue when more than one natural resource is present and within reach.

Combined, the existing treatments of natural resources in the literature provide a more comprehensive image of the role of natural resources in civil conflict, but still do not include the technical capacity or human capital constraints resource extractors face that may play a crucial role in determining the impacts of natural resources on civil conflict. For example, most of the existing classifications would assume that 'onshore oil' has a singular ability to be extracted and smuggled. However, onshore oil can be located in different types of deposits such as shale, sands, and reservoirs. The technical knowledge, equipment, and training required to extract natural resources from each of these types of deposits varies significantly and the resource also requires differing levels of processing post-extraction before it is sold as a commodity. While a group of rebels may be able to easily take control of an oil reservoir, or with sea access, a derrick, the technical knowledge and difficulty associated with extracting oil from oil sand deposits or by lateral fracking would require the assistance of on-site experts. To classify all types of onshore oil as having the same level of 'lootability' or as having the same 'point' or 'diffuse' distribution is therefore erroneous.

Human capital and technical requirements of natural resource extraction, contrary to a subjective assessment of 'lootability', offer an empirically consistent conceptualization of natural resources that can be objectively quantified and is replicable. The technical complexity of extraction based on site characteristics, reliance on equipment that requires specialized training, and the need for personnel with industry-specific expertise can be objectively assessed by industry experts, providing scholars with a clearer definition of what challenges rebels may face in obtaining and using funds from natural resources, regardless of their type or apparent 'lootability'.

\section{Natural Resources and Intrastate Conflict Location}


Early research into the civil war-natural resource nexus identified the possibility for natural resources to alter the location of civil conflicts (e.g. Buhaug and Gates 2002, Buhaug and Lujala 2005). These researchers fit into three broad camps which I discuss in this section.

The first camp argues that intrastate conflict locations are related to natural resource deposit locations. Econometric analyses support the idea that more armed actors arise in the presence of natural resources, which would inherently lead to more conflict in the presence of natural resources than in their absence. Furthermore, studies also show that ethnic conflicts are more likely to take place near diamond fields (Lujala et al 2005, Weinstein 2007). Weinstein (2007) shows that the relation to onset is the result of opportunistic armed actors crowding out the competition and using natural resources to incentivize recruits and fund conflict. Similarly, he argues that the presence of natural resources can encourage the formation of more armed actors, as these resources are easier to divide than something like external sponsorship. Lujala et al (2005) also finds that alluvial diamonds are associated with the occurrence of incidents of ethnic conflict.

The second camp argues that external stimuli can affect the geographic importance of a natural resource to civil conflict. For example, price shocks may help to determine where and when civil conflict over natural resources breaks out if opportunistic rebels choose to take advantage of natural resources when their market price increases. Quantitative support for this idea is found in the microlevel literature, which shows that dropping agricultural resource prices and increasing extracted or mined natural resource prices correlate to conflict in Colombia's natural resource-producing regions (Dube and Vargas 2013). In Darfur, resource pressure and the drive to control water and fertile agricultural land likely played a role in determining conflict location as well (Olsson and Shiba 2013).

A third camp argues that conflict zones tend not to be in resource-rich areas (Buhaug and Rod 2006). Furthermore, statistical analyses demonstrate support for the idea that belligerents will tend to avoid fighting over natural resources until a conflict is presumed to be ending (Hinkkainen and Kreutz 2019).

The three groups of findings present a set of puzzles for researchers. For instance, how can we reconcile the idea that natural resources can be used to fund and begin conflicts with the idea that civil conflict tends to occur outside of resource-rich areas and when armed actors fight over resources, they do so towards the end of a conflict? If price shocks determine when and where groups will fight over resources, why do alluvial diamonds seem to matter consistently to conflict onset?

The answers are likely not in the resources or their prices, but in the way we measure them. An opportunistic rebel group is less likely to be checking fluctuating market prices in nearby resources than evaluating if they have the manpower to take over and exploit a natural resource deposit. Alluvial diamonds are a good target for opportunistic rebels, as they do not require specific knowledge of the mining process or the ability to develop, build, and maintain specialized equipment.

Price shocks may matter for more high value resources, as they may encourage mining companies to invest in equipment and develop a natural resource deposit further or increase its production. Greater infrastructural development by a company means less investment on the part of a rebel group, making such resources potentially more appealing than they would have been if the rebel 
group had to provide infrastructure to develop the resource. However, multinational corporations often employ their own security forces to protect natural resource deposits which can deter armed actors from attacking. Support for the idea that the extra costs involved might deter rebels can be gleaned from recent examinations of the resource curse and conflict dynamics that demonstrate social protests increasing around the sites of active commercial mining operations, but find no comparable increase in rebel group activity or attacks (Christensen 2019). Armed rebel actors appear uninterested in taking control of large-scale complex mining operations that would require significant human capital or technical infrastructure to manage. As the CEO of the major mining corporation Randgold put it, "We've never--touch wood--had to stop operations (Christensen 2019)."

Where the onset of intrastate conflict is specifically concerned, some authors find that it is correlated with the past production of natural resources as opposed to their future potential (e.g. Humphreys 2005). Others reject this assertion in favor of a disaggregated approach that divides resources by type and production. Lujala et al (2005), for example, argues that secondary diamond production is correlated with intrastate conflict onset, whereas primary diamond production makes ethnic conflict onset less likely, attributing their findings to the 'lootability' of the resource. Ross (2004) takes a similar approach to Lujala et al (2005) by disaggregating resource type, yet finds that only oil is related to conflict onset. This is in stark contrast to Welsch (2008), who also disaggregates resources by type but determines that subsoil mineral resources, which he classifies as lootable and including bauxite, gold, and diamonds, are related to the onset of civil conflict.

While interesting, the disaggregation of natural resources by the type of resource in question misses the mark. To understand the role of natural resources in civil conflict onset, we must look beyond the resource type to the surrounding geological context and its impacts on the technical and human capital requirements of the resource's exploitation.

\section{Concept Definitions}

This paper focuses heavily on the role of mined resources and gemstones in determining how and where armed actors choose to engage in intrastate conflict. I argue that in order to understand the role of natural resources in conflict, we must begin with a scientific understanding of the context in which natural resources are located.

The geographical context of natural resources partially determines the level of human capital and technical capacity required in the extraction process. In this paper, I focus on four key types of deposits that we can categorize based on their geological features: surficial, sedimentary, metamorphic, and igneous. Surficial deposits are often easy to exploit, as the process may be as simple as removing visually apparent natural resources from exposed terrain. Sedimentary deposits may require some level of specialized skill or the ability to mechanically or chemically agglomerate or mine a given resource, but the surrounding materials are relatively soft. Artisanal mining operations often make use of sedimentary and surficial deposits. The more complex mining environments are metamorphic and igneous deposits, the most difficult to exploit natural resource deposits are igneous deposits, due to the 
extreme conditions under which they are formed ${ }^{3}$.

An additional deposit type, hydrothermal deposits, possess a complex relationship with extraction. These deposits vary widely in composition and value, and can be sedimentary, metamorphic, or igneous. When extraction is possible,it can be highly profitable. They may only be accessible after significant development however, and thus it is likely that armed actors would only be interested in engaging in conflict over fully-consolidated sites or past mines believed to potentially still be profitable and which closed for reasons other than perceived difficulty of extracting the remaining resources.

\section{Assumptions}

The theory I put forward in this paper rests on seven key assumptions. The first assumption is that the term "natural resource conflict" is a misnomer. Armed actors depend to varying degrees on natural resources, yet all conflicts involve actors making decisions regarding the use, acquisition, attack, control, sale, taxation, or consolidation of natural resources. In some cases, the decision is to avoid exploiting a given resource, while in others resource exploitation may play such a key role that it is perceived as a potential cause of the conflict. Thus, in some conflicts the role of natural resources may be more apparent than others. Attempting to identify an appropriate universe of cases that can be considered "natural resource conflicts" is a form of selecting on the dependent variable that is likely to lead to faulty inferences regarding the importance of these resources to conflict. Thus, all intrastate

\footnotetext{
${ }^{3}$ Surficial Deposits - Technically a class of sedimentary deposit, surficial deposits are sometimes referred to as placers, depending on the natural resources they contain. Placers are deposits that erode at a slower rate than the materials surrounding them. The high-value natural resources they contain are the leftovers after erosion and they can be found in soil or may be carried by water and wind to form parts of beaches, streams, sands, and gravels. Placers often contain natural resources such as alluvial diamonds, platinum group metals, sapphire, garnet, and gold (Chesterman 1978).

Sedimentary Deposits - Sedimentary deposits include clastic and chemical sedimentary formations. Clastic sedimentary deposits are formed by the deposition of gravel, mud, and sand over time. The compression of these materials as new layers accumulate leads to a process of cementation in which layers of conglomerated materials, sandstone, and shale are formed. The different materials are the result of different sized-grains within the deposit. The granular nature of these deposits is the result of the erosion-driven breakdown of prior igneous and metamorphic deposits, and as a result, the contents of sedimentary deposits are of similar composition to the deposits from which they arose (Chesterman 1978). Clastic deposits can therefore contain almost any mineral, gemstone, or metal resource, although mining these deposits may require the use of special materials. For example, sedimentary gold deposits may require an agglomeration agent such as mercury and access to water in order to process the metal into usable quantities. Chemical sedimentary deposits are not the result of deposition. They often arise due to evaporation and precipitation. Chemical sedimentary deposits may be large deposits of a single material, such as rock salt, borax, or gypsum, and these deposits are often highly-valuable (Chesterman 1978).

Metamorphic Deposits - Formed as a result of high temperature and pressure at depths of 3-20km within the Earth's crust, metamorphic deposits change one form of rock into another through deformation or destabilization of the minerals within the rock. There are three key types of metamorphism: contact, dynamothermal, and hydrothermal (Chesterman 1978). Hydrothermal deposits are treated as separate for this prospectus, as they can occur within other geologic deposit types, and are created via a smaller-scale process. Contact metamorphic deposits arise due to the combination of heat and fluid in deposits of rock located next to plutonic igneous deposits. Marble is one example of a rock resulting from this process. Dynamothermal metamorphic deposits arise as a result of large-scale deformations, such as the tectonic folding of multiple layers of rock in mountain ranges. The types of rock produced by these processes vary based on the pressure they underwent. Directed pressure results in materials such as slate and minerals such as calcite, chlorite, and epidote, whereas lithostatic pressure (confining or vertical pressure) creates high-quality marble, with minerals such as almandine garnet, fluorite, labradorite, and olivine (Chesterman 1978).

Igneous Deposits - Igneous deposits can be described as either plutonic or volcanic environments. Due to the high pressure, temperature, and the chemical composition of the magma involved in forming igneous deposits, they often contain crystallized minerals, gemstones, and precious metals such as copper, opal, gold, turquoise, topaz, and quartz. Pegmatites and carbonatites are particularly valuable igneous formations for industry, although carbonatites are sometimes classified as hydrothermal deposits, potentially due to the high concentration of calcium carbonate they contain (Chesterman 1978).
} 
conflicts are relevant to the study of "natural resource conflicts" and likely have natural resource-related dimensions.

Second, resources are used to fund conflict, but also as war booty. Thus, rebels have reason to pursue natural resources throughout a conflict, particularly if such resources are easy to obtain and cost little to exploit. However, armed actors are also likely to have a longer-term view that either seeks to prolong conflict in order to continue resource exploitation and avoid dealing with state debt and fiscal responsibilities that would come with taking control of the state itself, or to permanently control and consolidate resource-rich territory (Fairhead 2001). In the latter case, this may lead some resource-rich groups to settle with the government in order to protect their access to natural resource deposits and control over resource-rich territory, even as other groups continue fighting the state.

Third, armed actors are rational actors. This implies that they take into account not only the profits that natural resources may provide them with, but the costs they may incur in attacking, controlling, and exploiting such deposits. While natural resources are often perceived as a gain for armed actors and a profitable acquisition, there may be cases in which controlling a resource deposit is too expensive in terms of the technical capacity or expertise required to exploit the site or in manpower expended to fight for and control it, for the deposit to be profitable. Thus, armed actors may, as rational actors, choose not to attack or take control of natural resource deposits.

Fourth, rationality is bounded by information constraints. This implies that armed actors will act rationally as described in the previous assumption, but that their rationality is limited by the information they possess regarding the existence of, ability to fight for, control, and exploit natural resource deposits.

Fifth, rational actions are bounded by material capabilities. This assumption is closely related to the prior assumption regarding information limitations, but is not identical. The implication of assumption five is that if a rebel group has information regarding a natural resource deposit, including the difficulty they may encounter in fighting for control of it or exploiting the resource itself, the rebel group's decision to attempt to control the deposit may still be influenced by external factors such as, but not limited to, changes in the market value of the resource or an expenditure in fighting forces at another location that is more urgent than resource control.

My sixth assumption is that, while access to markets is necessary, in many cases it is not difficult for armed actors to obtain market access and sell the resources they obtain in conflict. Significant efforts have been made via the Extractive Industries Transparency Initiative, Kimberlee certification process, Dodd-Frank 1502, and other policies and programs aiming to prevent 'conflict' resources infiltrating international markets. However, these efforts have resulted in the creation of a two-tiered market within which conflict-free resources fetch a higher price, but those resources that are not certified as conflict-free are still bought, sold, and traded (Enough Project 2018). For example, when the Kimberlee certification program put a ban on raw diamonds being exported from the Central African Republic and then President Catherine Samba Panza sought to enforce traceability of gems, local trading houses bought and stockpiled rebel mined diamonds for sale after the ban was lifted. Those diamonds that could not find local buyers were trafficked to Chad, Dubai, Antwerp, 
India, and other prominent international diamond markets (Flynn 2014). Thus, while market access is more difficult for armed actors than it was prior to the creation of these programs, groups are still able to market the resources they obtain.

My seventh assumption is that resource predation can be greed-based and grievance-driven; it can create opportunities for new groups, encourage fighters to be more willing to participate in conflict, and provide motivation for autonomy or the control of specific swaths of territory. To argue that resources affect only one of these factors oversimplifies their impact on intrastate conflict, and may lead to falsely dichotomous comparisons between motivations when both are present or the nature of the factor which creates or allows conflict to propagate changes over time.

\section{Theory}

In this section, I begin by describing the underlying theory on which I base this paper. I support the theory with evidence from prior empirical investigations and case study research. I dive deeper into how my theory predicts natural resources will impact conflict location. Taking into account the assumptions discussed in the preceding section, I argue that armed actors will pursue natural resources during conflict, but their pursuit will be informed by cost-benefit analyses that take into account the human capital and technical capacity needed to extract natural resources.

The existing economic explanations for the role of natural resources in civil war are incomplete. At present, attempts to assess the importance of natural resources to civil conflict are severely limited in their scope and ability to explain conflict-related effects across natural resource types. Existing conceptualizations of natural resources in the conflict literature have led to numerous mixed findings. None of the existing descriptions (e.g. point vs. diffuse, resource type, economic value, primary commodity export dependence) pays heed to geological and engineering factors which affect the ease of exploiting a given natural resource deposit. Some, such as the dependence on primary commodity exports measure, commit an ecological fallacy in assuming that a national-level measure can be used to predict processes at the subnational level. As a result, existing descriptions of natural resources also overlook the factors which likely offer the most insight for social science examinations: the human capital and technical capacity requirements of the exploitation process. Contrary to common conceptualizations of natural resources as easy pickings for armed actors, I argue that the presence of a natural resource does not equate to opportunity unless a rebel group's cost of exploiting the natural resource deposit is lower than the gains it makes from exploiting the natural resource deposit.

Even when a natural resource is located within their territory, armed rebel actors do not pursue natural resource deposits at will. Rebel actors' pursuit of resource control takes place within the context of an ongoing conflict. As seen with jadeite deposits in Kachin State in Myanmar, state militaries can behave in much the same way that armed actors do. Rather than acting as a legitimate state organization, they often compete with armed rebel actors over the control of natural resources in direct and indirect ways. Myanmar's Tatmadaw (state military) often control or partner with extraction companies, many of whom are front organizations for Chinese companies. The tailings 
from their mines are dumped nearby the jadeite mine sites, where thousands of pickers--miners who make their living by combing through the tailings to find potentially overlooked jadeite stones--make a living from jade and stay alive by paying taxes to the Kachin Independence Army (KIA), a rebel group. The KIA's extortion of local pickers is coupled with and complicated by the heroin trade in the Hpakant region where the mines are located and from which armed actors profit (Beech n.d.). At the same time, the Tatmadaw has also directly engaged in conflict with the KIA and other armed actors over control of mining territory. Complicating things further however, it is cooperation with the Tatmadaw that allows armed actors such as the KIA to profit. As the KIA's information officer, Col. $\mathrm{Naw} \mathrm{Bu}$, stated,

... as everyone knows, nobody can do business such as gold, amber and jade mining without the involvement of the Tatmadaw and the government. The KIA alone can't contact foreign businessmen to come [to the mines]. I mean the KIA can't do that without tactical commanders, brigade commanders and battalion commanders on the [Tatmadaw's] front lines. The two sides might have some disputes about sharing profits, and that's why [the Tatmadaw] is complaining about the legality of those mines now (Pwint 2018).

Rebel actors must take the complexity of the exploitation context and relations with 'legitimate' institutions into account when calculating whether or not a given resource is worth exploiting or fighting to control. In the heart of Kachin state in Myanmar, the KIA has fought the Tatmadaw over resources directly. The resources are located in difficult to navigate territory that they control, and where they are largely surrounded by ethnic kin and supporters. In the Hpakant region of Kachin state however, their calculus is different. The group does not consistently fight over the Hpakant mines; the Tatmadaw is strong in Hpakant, backed by Chinese interests and a migrant worker population that came to the areas mines with the goal of striking it rich. Hpakant is connected to a highway and river, facilitating transit in and out of the area, although access to Hpakant itself is tightly controlled. Knowing the strength of the Tatmadaw, the KIA indirectly profits off of the resources by extorting 'jade table ${ }^{4}$ ' traders and mining pickers rather than directly confronting the military (Beech, n.d.).

The current situation in Hpakant is changing. Hpakant had once been home to small, illegal mining operations run by the KIA, local Kachin civilians, and supporters of the KIA. When the Tatmadaw gained control of Hpakant's mines and brought in multinational corporations, heavy-duty equipment, and large vehicles for more intense jadeite exploitation, the KIA and the local Kachin were marginalized (Beech, n.d.). They fought back at first, but as the mining population shifted, the KIA found itself with less local support and a greater need to rely on more indirect exploitation tactics for

\footnotetext{
4 'Jade tables' are trading facilities where pickers can sell the stones they recovered from the mine tailings to middle men who then sell them to Chinese multinational corporations, mining companies run by Burmese military elite, and others (Beech n.d.).
} 
steady income. However, this is KIA territory, so the fighting continues, even as local populations flee (Hogan 2018).

I argue that as human capital and technical capacity requirements increase for a given natural resource deposit, fighting over and around it should decrease. Armed actors will pursue control of natural resource deposits that require the least human capital and technical capacity to exploit for the highest economic gain. This potentially implies that easy to grab resources from surficial deposits and high-value natural resource deposits that are difficult to exploit without significant human capital will face less conflict than mid-range natural resources that offer higher economic output for less human capital and technical expertise. Surficial deposits such as alluvial diamonds should be more appealing as conflict resources than difficult to extract resources that require significant technical capacity and human capital to exploit.

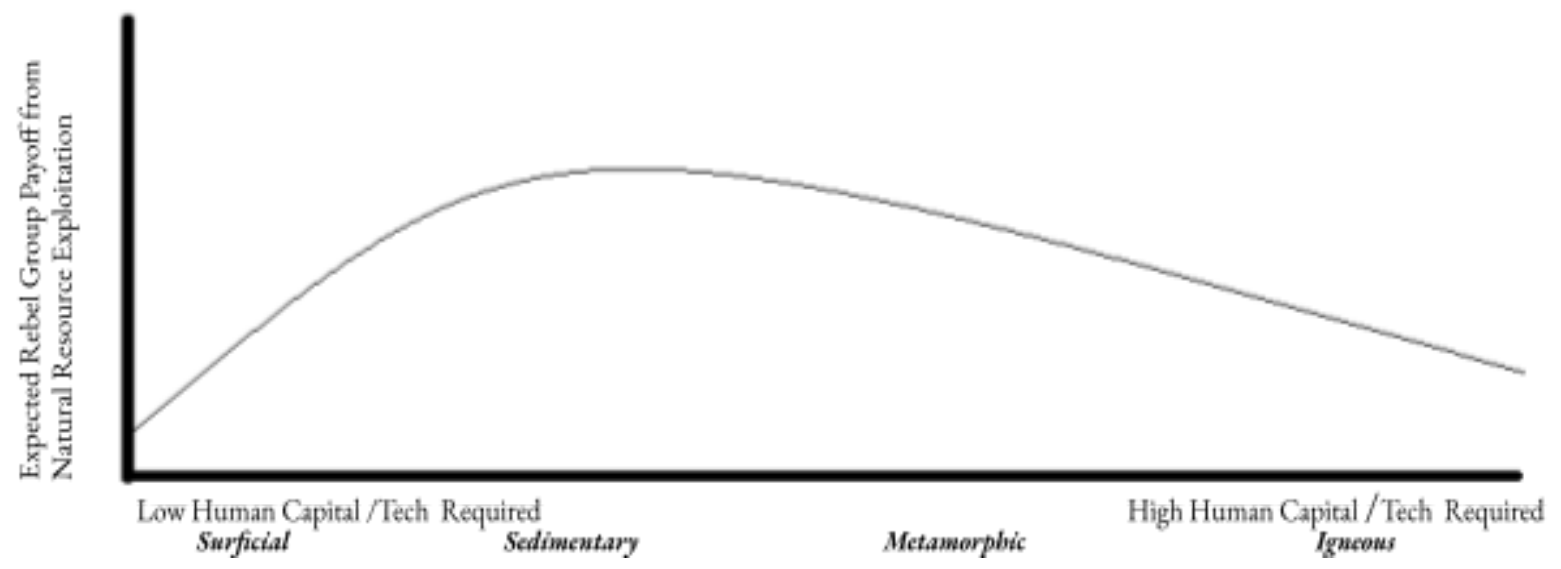

Figure 1: Expected rebel group payoff from natural resource exploitation based on the buman capital and technical requirements of exploiting a given natural resource deposit.

If a natural resource has already been developed and infrastructure for natural resource exploitation installed, armed actors will be more interested in conquering it if human capital requirements are low than if they are high. If human capital requirements are relatively similar, armed actors will be more interested in controlling natural resource deposits that require less technical capacity than those that require greater technical capacity. However, if no human capital or technical infrastructure investment is required by armed actors, their desire to control and consolidate the resource should be low, as well. The cost of fighting would not be worth it to hold a deposit that can easily be exploited and represents a low cost for the rebel actor to exploit, even without territorial control.

If a group does not have access to the human capital and technical expertise necessary to exploit a natural resource deposit but is strong enough to militarily control a zone, it may resort to taxation of natural resource deposits in order to raise funds. In the La Centrale area of Cote d'Ivoire for example, the Forces Nouvelles created a system of taxation that allowed for the exploitation of artisanal diamond mining sites (Hazen 2013). The group may not have been able to exploit this 
valuable resource otherwise, as the diamond mines in this region are located in deposits that are too difficult and expensive to profitably access without significant human capital and technical capacity (Handloff 1988, Wright 1985).

To execute and survive the implementation of strategies for resource exploitation and conflict, armed actors must account for the strength of their opposition and weigh carefully who their opponent is. Armed actors must also carefully evaluate who currently controls the mine. In the Democratic Republic of the Congo for example, armed rebel actors forced labor in four mines, engaged in illegal taxation in 35 others, bought minerals in two, and directly extracted minerals themselves in one (Malango 2016). Why do they practice different tactics at different mine sites?

I argue that mines with foreign backers are likely to be unappealing targets for control, although they make good targets for exploitative taxation. Thus, armed actors are less likely to fight state forces over mines with foreign backers. This is because armed actors would have to be able to either convince the foreign backers to stay on despite the conflict or to replace the infrastructure and human capital investments made by the foreign backers whilst gaining market access for the natural resources within the deposit. Likewise, the presence of foreign funding to exploit natural resources is a likely indicator that the exploitation process is more technically complex than the mining of small-scale artisanal mines. For this reason, many foreign firms also bring their own people to build, run, and extract natural resources. China, for example, has invested more than half of its total outbound investment in extractive industries of foreign countries between 2005 and 2016 (Mining Technology 2018). According to Tom Wegenast, a researcher examining Chinese extractive industry operations in Africa,

It's more or less safe to say that Chinese companies employ less local labour than other
companies because they bring over many Chinese workers... and when they [the Chinese] develop
local infrastructure, they provide countries with loans which are being used to pay for it, which is
then constructed by Chinese companies and Chinese labour (Mining Technology 2018).

If it were affordable without foreign involvement, local natural resource exploitation companies would likely retain control over their natural resource deposits, build their own infrastructure, employ local labor, and sell the resources on international markets without dealing with foreign intermediaries.

Unlike a mine with foreign investors, mines controlled by local artisanal miners may be appealing targets. Locals can be conscripted as free labor if the exploitation of the natural resource in the deposit does not require significant human capital. When easy-to-extract natural resources are under their control, armed actors may abuse locals more readily (Wood 2014). The loss of free labor is not of concern to armed actors as reliance on natural resource deposits frees them from needing to treat local populations well. They can substitute labor with capital. Foreign investment is likely required in complex extraction environments such as oil sands that require specialized equipment and on-site engineers around the clock or pegmatite deposits in igneous or metamorphic structures that necessitate the use of explosives and specialized chemicals and equipment to extract. Sedimentary 
deposits can be easily exploited, however. Many require little to no specialized equipment, and the payoff can be high depending on the resource being extracted.

When local human capital is employed to exploit a resource, armed actors have incentive to treat the locals well. The presence of local human capital at a site likely reflects expertise regarding the specific techniques needed to extract the resource within the deposit, and yet such human capital does not bring with it the international attention that attacking and controlling a deposit controlled by foreigners might incur (Stewart et al FORTHCOMING). Human capital is capable of relocating, however. Many refugees are not poor, they are wealthy enough to move and educated enough to understand the risks of remaining in a conflict zone. To prevent local human capital from relocating, armed actors may provide public goods and services, establish governing institutions, and develop a social contract that seeks to balance the group's goals in profiting from the resource while providing locals with a sense of security and order (Stewart et al FORTHCOMING).

Surficial natural resource deposits do not make ideal sites for a rebel group to fight over. The resources they hold can be quickly and easily gathered, and exploiting the local miners, traders, and companies that run the sites via extortion schemes would likely be more profitable than holding the deposit itself. Raiding such deposits and smuggling resources from them is also likely to be relatively easy. A rebel group holding such a deposit in its territory would not be likely to stand their ground and fight if challenged for control. Rather, as the KIA did in Myanmar's Kachin state, they may switch to the taxation and exploitation of workers and companies directly involved in the extraction site while avoiding direct confrontation with state armies. Likewise, as the KIA did with the Tatmadaw (Pwint 2018), armed actors may find ways to cooperate and work with their opponents in the exploitation of natural resources at surficial natural resource deposits.

Outside of the socio-economic considerations of natural resource exploitation, geological and geographical concerns come into play. Natural resource deposit locations are partially determined by the same factors that influence terrain. The tectonic movement of plates and volcanic activity that result in the formation of mountain ranges, the erosion that creates sandswept landscapes, the flooding and rains that result in the deposition of sediment, each affect directly affect the topography of an area as well as the characteristics of natural resource deposits that exist within it. Armed actors can take advantage of mountainous terrain associated with some igneous and metamorphic deposits for protection, and may be more exposed and at risk of attack on the flat landscapes that are characteristic of some sedimentary and surficial deposits. Mountains can also include sedimentary and surficial deposits however, and not all igneous or metamorphic deposits are located on flat land. Regardless of the types of natural resource deposits they target, armed actors must weigh concerns regarding their vulnerability to attack based on the geographical position of deposits. The distance from nearby waterways and roads can directly impact how quickly and easily armed actors can get natural resources to markets or make use of funds they obtained through resource taxation. The shorter the trip to markets where natural resources can be sold or weapons obtained, the more appealing a natural resource deposit is likely to be for armed actors that seek to fund their war efforts. 
Nearby porous borders can be beneficial to armed actors, providing access to markets that are not a part of the state they are fighting, and potentially allowing for arms trafficking. For example, in Liberia the Oriental Timber Company hauled lumber out of the state and brought weapons back to supply rebels from 2000-2003 (Bowcott 2017). The United Wa State Army in Myanmar benefits strongly from a porous border with China, which facilitates the rebel group's ability to obtain weaponry and sell opium, methamphetamines, and other natural resources (Dillabough-Lefebvre 2019). Natural resource deposits located near international borders may therefore be particularly appealing, particularly if the state on the other side of the border supports the rebels' efforts.

\section{Implications for Conflict Onset and Location}

Weinstein (2007) demonstrated that a greater number of armed actors form in regions endowed with natural resource wealth than in those devoid of it. However, at the start of a rebel group's operations, capacity is likely to be low. Hence, new armed actors are unlikely to be able to exploit a natural resource that requires significant human capital.

The human capital and technical capacity required to extract a natural resource partially determine which natural resource deposits armed actors are likely to exploit and how. I argue that the investment required for natural resource exploitation of more human capital intensive and technically complex natural resources will result in greater territorial consolidation of the area surrounding these resources and a higher propensity for groups to engage in conflict in order to protect these deposits. However, when deposits present significant technological or human capital demands, armed actors should be less inclined to seek control of the deposit, as tactics such as exploitation or taxation may prove more effective and cost armed actors less to undertake. This is particularly likely if the deposit is mined by multinational corporations which employ their own militarized security guards.

When a resource requires significant human capital to extract, the assistance of multinational corporations may be necessary in order to take advantage of the resource. Likewise, even if multinational corporations are not involved in the extraction process, technical experts would be required. To encourage human capital not to leave the zone of resource control, armed actors would need to either consolidate the resource-rich territory or resort to tactics such as taxation, extortion, or raiding in order to profit from the natural resource deposit.

Tentative support for this portion of the theory exists in recent studies examining the decision to establish rebel governance in natural resource-rich areas. When a rebel group has access to easily lootable resources, they are less likely to establish governance institutions. When immobile assets such as industrial infrastructure are present in a zone, armed actors are more likely to establish governance institutions and avoid tactics such as plundering or raiding the natural resource. Rather, they will encourage economic productivity in order to increase their potentially taxable revenue (Florea, FORTHCOMING). This also explains why, when a rebel group is involved in natural resource extraction, they are more likely to provide health services (Stewart et al FORTHCOMING).

Providing public goods is a costly endeavor, and unlikely to be sustainable over time. Natural resource extraction equipment failures may occur and purchasing new extraction equipment may be 
difficult for a rebel group depending on its relations with external actors and perceived international legitimacy. Likewise, relationships with multinational corporations may be difficult to maintain and finding a market for the resource itself may face hurdles such as international certification processes that may reduce the value of the resource on the market or otherwise impinge on the profits a rebel group is able to obtain from natural resource control and extraction. Thus, conflicts involving rebel control of human capital-intensive resources are likely to be shorter, due to the constraints placed on armed actors by the need to maintain the human capital and technical capacity to exploit and profit off of the natural resources under their control.

The implications of the preceding section are numerous, as are the limitations of existing datasets which might be used to test the theory. In order to examine the empirical validity of the theory described above, I begin with the careful selection of a set of hypotheses which address the underlying logic of the theory. In the proposed dissertation, I plan to address three dependent variables.

In sum, I argue that the difficulty in resource extraction affects armed actors' calculus of how to behave in conflict. Extraction difficulty is directly impacted by the geological characteristics of the site which affect the need for varying levels of human capital and technical capacity. An approximation of the technological and human capital requirements for natural resource extraction from different types of natural resource deposits can be made using knowledge of the mineral envelope surrounding the resource deposit. Human capital and technical capacity are likely to often be substitutes for one another but not always, as some sites such as oil sand deposits will require high human capital and technical capacity. Furthermore, I argue that armed actors are aware of the need for varying levels of human capital and technical capacity in natural resource extraction sites and this directly informs their calculus of how, when, and where to engage with these deposits and the communities surrounding them.

\section{Hypotheses}

H1: The presence of sedimentary resources in an administrative unit increases the likelibood of state-based and non-state violent conflict in that administrative unit.

DVs: Count of total state-based conflict events in a given administrative unit, count of total non-state conflict events in a given administrative unit, count of total state-based and non-state conflict events in a given administrative unit.

Key IV: Count of the total number of sedimentary deposits in a given administrative unit

H2: The presence of igneous or metamorphic deposits in an administrative unit decreases the likelibood of state-based and non-state violent conflict events in that unit.

DVs: Count of total state-based conflict events in a given administrative unit, count of total non-state conflict events in a given administrative unit, count of total state-based and non-state conflict events in a given administrative unit.

Key IVs: Count of the total number of igneous deposits in a given administrative unit, count of the total number of metamorphic deposits in a given administrative unit. 
Taking into account the theoretical discussion above, I propose the following thought model as representative of the calculus armed actors consider prior to engaging in conflict over a given natural resource deposit:

Conflict Location $=f($ Human and technical capacity required for extraction + presence of gold deposits + presence of diamond deposits + presence of other natural resource deposit options)

Subject to $d y / d x$ buman and technical capacity required for extraction $<0, d y / d x$ presence of gold deposits $<0, d y / d x$ presence of diamond deposits $<0, d y / d x$ total number of other natural resource deposit options $>$.

\section{Data and Methods}

There are limitations to the available data which make in-depth examination of the proposed theory difficult. For example, at present it is not possible to obtain specific information regarding the number of individuals actively working at each resource extraction site in the world or to make an inventory of the equipment at each site. What can be done to test the theory is to simplify, as all models do.

The conceptualization of natural resources I propose may also help to resolve inconsistencies in the empirical record on issues of conflict location and severity. For example, Weinstein (2007) and Wood (2014) have contradictory findings regarding how rebels will treat local populations in contexts of natural resource wealth. I argue that this discrepancy exists as a result of the inability to address this question without accounting for the aspect of natural resource wealth most likely to affect the relationship between local populations and armed actors: the complexity and required expertise, and hence the reliance on local communities, needed to extract natural resources.

In this section, I begin with a discussion of the choice of quantitative testing strategy and within that discussion, the choice of dependent variables, independent predictor variables, and controls for the study, as well as the choice to use a negative binomial regression strategy. Following the discussion of the econometric modeling strategy, I discuss the creation of the dataset used in this project, which is designed for public release and is a major contribution of the paper itself.

\section{Methods}

This paper uses the information in the dataset to approximate the human capital and technical capacity needed to extract natural resources by difficulty of accessing a deposit, regardless of whether the minerals contained within it are gold, diamonds, gemstones, or something else. The unit of analysis for the quantitative portion of this proposed paper is the administrative unit.

One benefit of the proposed conceptualization of natural resources along an index based on the human capital and technical capacity required to extract the resource is that it allows for simpler models to account for otherwise complicated and spatially-bound features. For example, although the nature of this project is spatial in its description, spatial regression is not necessary to test the hypotheses when the data are converted into points-per-polygon measures, as they are in the new dataset created as part of this project. The resource characteristics of resources within a specific geographical unit of analysis (i.e. administrative unit) allow for examination of conflict without the 
use of a spatial regression, while taking into account the site-specific characteristics of natural resource deposits.

The dependent variables for this study are count measures for the number of incidents of non-state and state-based violent conflict within a given administrative unit, and the total of both non-state and state-based violent conflict within a given administrative unit. The third dependent variable is a sum of the first two and encompasses all intrastate violent conflict events that do not target civilians. I run a separate model for each form of violent conflict, as well as an additional model for violence that expressly targets civilians (i.e. one-sided violence).

Data for the dependent variables was drawn from the Uppsala Conflict Data Program's (UCDP) Georeferenced Event Data (GED), v. 19.1. The data in the UCDP GED dataset is disaggregated by individual violent events and coded geographically. I sum the number of events in each administrative district to produce a time-independent count variable for the number of violent conflict events of each type per administrative district.

The resulting data for the dependent variable is highly dispersed for each of the dependent variables, suggesting that Ordinary Least Squares would not be an appropriate estimator in this instance. As the data is count data, I initially attempted to use a poisson estimator. A Pearson chi-squared goodness-of-fit test revealed that the poisson model was also inadequate however, and the difference between the variance and the mean for each of the dependent variables indicates that the data is over-dispersed. As a result, I opted to employ a negative binomial estimator.

The independent variables of interest for this study are the total number of sedimentary, igneous, and metamorphic deposits in a given administrative unit. The control variables for this study are the total number of surficial, gold, diamond, and hydrothermal deposits in a given administrative unit. Data for these variables was drawn from the United States Geological Survey's (USGS) Mineral Resources Online Spatial Data. As with the conflict data, I created count measures for this data by summing the number of deposits of each type for each administrative unit included in that data. An in-depth discussion of the creation of the dataset used for this project is provided in the following subsection.

\section{The Dataset}

A key contribution of this paper is the creation of a new count dataset that allows researchers to compile the characteristics of a resource deposit in order to either test the importance of individual resource types or categories of natural resources on violent conflict. At present, the dataset does not account for temporal variation. Current GADM (as of 2018) designations have been used to identify the physical location of resources and violent events. The sample encompasses all administrative units in the USGS Mineral Resource Online Spatial Data as well as all administrative units included in the UCDP Georeferenced Event Dataset v. 19.1. The conflict events included in the dataset occurred between 1989-2018 (Hogbladh 2019, Sundberg and Melander 2013).

Information on the number and location of 93 different types of mineral deposits is included in the dataset, together with the classification of their geological setting as surficial, sedimentary, 
metamorphic, igneous, or hydrothermal. Additional variables indicating whether deposits contain gemstones, the number of gemstone deposits, the presence of natural resources in mixed geological settings, unclassified deposit types, and the total number of natural resource deposits is also included in the dataset. Data on the type and classification of natural resources and their geological settings was drawn from the United States Geological Survey's Mineral Resources Online Spatial Data repository (USGS 2019) and was updated with the help of an undergraduate environmental sciences research assistant. ${ }^{5}$ Violence count data is drawn from and classified according to the UCDP Georeferenced Event Dataset v. 19.1.

To create the dataset, I conducted a points-in-polygon analysis by collapsing and summing the number of events or deposits for each of the variables in the source data and used the resulting data as count variables in the new dataset. Each data point was checked for geographic accuracy, and when necessary and possible, the secondary administrative unit geographic identifiers were updated using a combination of the point coordinates, place name identifiers, and hierarchical administrative subdivision $\operatorname{codes}^{6}$ provided in the source data and updated when necessary and possible.

The dataset uses a secondary administrative unit identifier. Additionally, the dataset uses the UCDP Georeferenced Event Data to determine the location and type of conflict events. The resulting dataset retains the administrative unit data, absent spatial coordinates.

\section{Analyses and Results}

The underlying logic of my theory can be tested using information on the geological characteristics of natural resource deposits. I argue that fighting over surficial deposits makes little sense. Such deposits require no investment on the part of armed actors and can be easily raided. There is only a weak incentive to fight over these resources. Igneous and metamorphic deposits are even less unappealing. They are too difficult for armed actors to exploit without significant assistance and often have foreign multinational companies present whose security teams represent an additional obstacle to extraction and new foes to fight should a rebel group choose to target these sites. On the other hand, sedimentary deposits represent an investment due to the greater complexity they offer compared to surficial deposits, but do not require the same, intense investment in human capital and technical capacity that igneous and metamorphic deposits are likely to incur. Thus, more violence should occur at sedimentary deposits than surficial, igneous, or metamorphic deposits. Hydrothermal deposits and critical minerals are discussed briefly, but are not the key focus of this analysis, as they are not truly distinct deposit types. Hydrothermal deposits are frequently sedimentary, whereas critical minerals occur in a variety of deposit types.

\footnotetext{
${ }^{5}$ The research assistant generated a new variable for deposit classifications that characterized deposits by their mineral envelope using publicly available geological data when the deposit type itself was left as unclassified in the USGS data.

${ }^{6}$ As available in the GADM (2018) and updated using the data on Statoids.com between August 14th-20th, 2020.
} 
These preliminary analyses speak to and support the underlying logic of my theory. The ability to conduct a preliminary analysis of the hypotheses proposed in this paper is limited by an inability to precisely measure the human capital and technical capacity required at each mining site using existing observational data. To partially overcome this limitation, I used data from the United States Geological Survey's data on the locations and geological characteristics of natural resource deposits around the world.

Due to the count nature of the data and the issues with goodness of fit and overdispersion of the data mentioned earlier, I ran a series of negative binomial models (see Table 1, below). Model 1 uses the number of state-based conflict events as the dependent variable. Model 2 uses the number of non-state conflict events as the dependent variable. Model 3 uses the number of one-sided conflict events as the dependent variable. Finally, model 4 uses the total number of violent conflict events that did not target civilians as the dependent variable. Each of the models includes count variables for the number of igneous, hydrothermal, metamorphic, sedimentary, surficial, gold, diamond, and overall natural resource deposits.

Looking at the results, the key variables of interest carry the expected signs and are significant in most models. For example, as the number of igneous deposits increases, the likelihood of violent conflict events in a given administrative unit decreases. This is statistically significant across all models at the $\mathrm{p}<0.01$ level. Metamorphic deposits also appear to decrease the likelihood of violent conflict events, carrying a negative sign across all models, although only statistically significant in Models 2,3 , and 4 . Sedimentary deposits behave as expected according to the theory, exerting a positive influence on the likelihood of violent conflict events across all models. The influence of these deposits is significant in Models 1 and 4 at the $p<0.05$ level and in Model 2 at the $p<0.01$ level. Sedimentary deposits do not exert a statistically significant influence on the likelihood of nonstate violent conflict events, although the coefficient does still carry the expected positive sign.

Surficial deposits have mixed results, but this is not surprising. They strongly and significantly decrease the likelihood of state-based conflict at the $\mathrm{p}<0.01$ level and exert statistically insignificant but negatively signed influence on non-state and total non-civilian targeting violence. However, where one-sided violence is concerned, their impact is statistically insignificant but positive. The way that rebel groups relate to civilian populations in the context of easily obtainable resources is debated in the literature, and mixed findings on the treatment of populations in areas rich in easily lootable resources are present and confirmed at both the micro and macro levels (see, for example, Weinstein 2007 and Wood 2014).

Hydrothermal deposits, which are often at least partially sedimentary in nature, demonstrate weak positive influence on the likelihood of state-based, one-sided, and total non-civilian conflict events. This effect is only statistically significant at the $p<0.05$ level in Models 1 and 4 and is not statistically significant in Model 3. Model 2, which addresses the infighting of rebel groups and other non-state armed actors, is negatively signed and not statistically significant. This potentially results from the mixed mineral envelope and complexity of such deposits, and warrants further investigation in future studies. 
Gold and diamonds, chosen as controls due to the frequent discussion and mixed findings of their impacts on civil conflict, appear to strongly increase the likelihood (at the $p<0.01$ level) of one-sided and total non-civilian targeting violent events. This suggests that the presence of these resources does increase the baseline risk of conflict in an administrative district, but it is also interesting to note what the results suggest they do not do. Gold appears to decrease the likelihood of state-based violent conflict events at the $\mathrm{p}<0.01$ level, and exerts a statistically insignificant impact on the number of non-state conflict events. Diamond-rich administrative units appear more likely to experience a greater number of nonstate violent conflict events, but the effect is only significant at the $\mathrm{p}<0.05$ level. Although the coefficient is positively signed, diamonds do not exert a statistically significant impact on the number of state-based conflict events.

As the total number of natural resource deposits in a given administrative unit increases, it appears to significantly decrease the likelihood of state-based and total non-civilian targeting violent conflict events. The negative coefficient is also present in Model 3, which addresses violence towards civilians, but the sign flips for conflict events between rebel groups and other non-state armed actors. In general, this makes sense. Stronger administrative units and states that have significant resource wealth may be better able to prevent the emergence of rebel groups. When such groups do arise, more infighting over local resource control may occur than fighting with the state. 
Table 1: Negative Binomial Estimations of the Differences in Conflict Event Counts as Influenced by the Presence of Natural Resource Deposits

\begin{tabular}{|c|c|c|c|c|}
\hline & 1: State Based & 2: Nonstate & 3: One-sided & 4: Total Non-Civilian \\
\hline Igneous & $\begin{array}{l}-0.086^{* *} \\
(0.003)\end{array}$ & $\begin{array}{l}-0.017^{* *} \\
(0.002)\end{array}$ & $\begin{array}{l}-0.029^{* *} \\
(0.002)\end{array}$ & $\begin{array}{l}-0.045^{* *} \\
(0.002)\end{array}$ \\
\hline Hydrothermal & $\begin{array}{l}1.620^{*} \\
(0.717)\end{array}$ & $\begin{array}{l}-1.893 \\
(1.435)\end{array}$ & $\begin{array}{l}0.777 \\
(0.646)\end{array}$ & $\begin{array}{l}1.498^{*} \\
(0.657)\end{array}$ \\
\hline Metamorphic & $\begin{array}{l}-0.013 \\
(0.096)\end{array}$ & $\begin{array}{l}-0.367^{* *} \\
(0.135)\end{array}$ & $\begin{array}{l}-0.325^{* *} \\
(0.087)\end{array}$ & $\begin{array}{l}-0.223^{* *} \\
(0.074)\end{array}$ \\
\hline Sedimentary & $\begin{array}{l}0.253^{*} \\
(0.122)\end{array}$ & $\begin{array}{l}0.071 \\
(0.152)\end{array}$ & $\begin{array}{l}0.477^{* *} \\
(0.118)\end{array}$ & $\begin{array}{l}0.165^{*} \\
(0.084)\end{array}$ \\
\hline Surficial & $\begin{array}{l}-5.089^{* *} \\
(0.809)\end{array}$ & $\begin{array}{l}-0.248 \\
(0.268)\end{array}$ & $\begin{array}{l}0.199 \\
(0.241)\end{array}$ & $\begin{array}{l}-0.173 \\
(0.158)\end{array}$ \\
\hline Gold & $\begin{array}{l}-1.556^{* *} \\
(0.289)\end{array}$ & $\begin{array}{l}0.448 \\
(0.232)\end{array}$ & $\begin{array}{l}0.716^{* *} \\
(0.175)\end{array}$ & $\begin{array}{l}0.574^{* *} \\
(0.128)\end{array}$ \\
\hline Diamond & $\begin{array}{l}1.355 \\
(0.708)\end{array}$ & $\begin{array}{l}1.672^{*} \\
(0.800)\end{array}$ & $\begin{array}{l}2.024^{* *} \\
(0.532)\end{array}$ & $\begin{array}{l}1.607^{* *} \\
(0.503)\end{array}$ \\
\hline Total Resource Deposits & $\begin{array}{l}-0.229^{* *} \\
(0.072)\end{array}$ & $\begin{array}{l}0.149 \\
(0.127)\end{array}$ & $\begin{array}{l}-0.142 \\
(0.079)\end{array}$ & $\begin{array}{l}-0.225^{* *} \\
(0.066)\end{array}$ \\
\hline Constant & $\begin{array}{l}2.065^{* *} \\
(0.027)\end{array}$ & $\begin{array}{l}-0.094^{*} \\
(0.044)\end{array}$ & $\begin{array}{l}0.654^{* *} \\
(0.030)\end{array}$ & $\begin{array}{l}2.122^{* *} \\
(0.025)\end{array}$ \\
\hline Ln alpha cons & $\begin{array}{l}2.270^{* *} \\
(0.016)\end{array}$ & $\begin{array}{l}3.242^{* *} \\
(0.029)\end{array}$ & $\begin{array}{l}2.509^{* *} \\
(0.021)\end{array}$ & $\begin{array}{l}2.115^{* *} \\
(0.015)\end{array}$ \\
\hline$N$ & 16,086 & 16,086 & 16,086 & 16,086 \\
\hline
\end{tabular}

Although the coefficients themselves are intriguing, the interpretation of negative binomial estimations can be challenging. Negative binomial coefficients indicate the change in logged expected counts of the dependent variable as a result of a one-unit change in the independent variable, holding all other variables in the model constant. Marginal effects plots can help to visually assess the impact of independent variables in such models. As a result, I include marginal effects plots of the effects of each variable in the model on the predicted number of violent conflict events of each type in Figures 2-5, below.

Notably, in none of the figures do we see surficial deposits as playing a crucial role in the determination of the location of violent conflict events. This flies in the face of theories that expect simple lootability to drive the impact of natural resources on conflict and also supports the theory put 
forth in this paper, which argues that sedimentary deposits should play a more important role in increasing the likelihood of violent conflict within a given administrative unit.

Support for hypothesis 1 is clearly present in the state-based, one-sided, and total non-civilian targeting conflict models, but is absent for the non-state model. Support for hypothesis 2 is clearly present for metamorphic deposits regarding total violent conflict events not targeting civilians, as well as for one-sided and non-state conflict events, but absent for state-based conflicts. Where igneous deposits are concerned the results are more interesting. Igneous deposits do, as expected, exert a negative impact on the likelihood of all conflict event types, with the exception of nonstate conflict events. The effect is much weaker than expected, however.

Notably, the difference between the deposit types proposed by the theory discussed in this paper clearly matters for state-based, one-sided, and total non-civilian targeting violent conflict events, but does not appear to be important for non-state violence events.

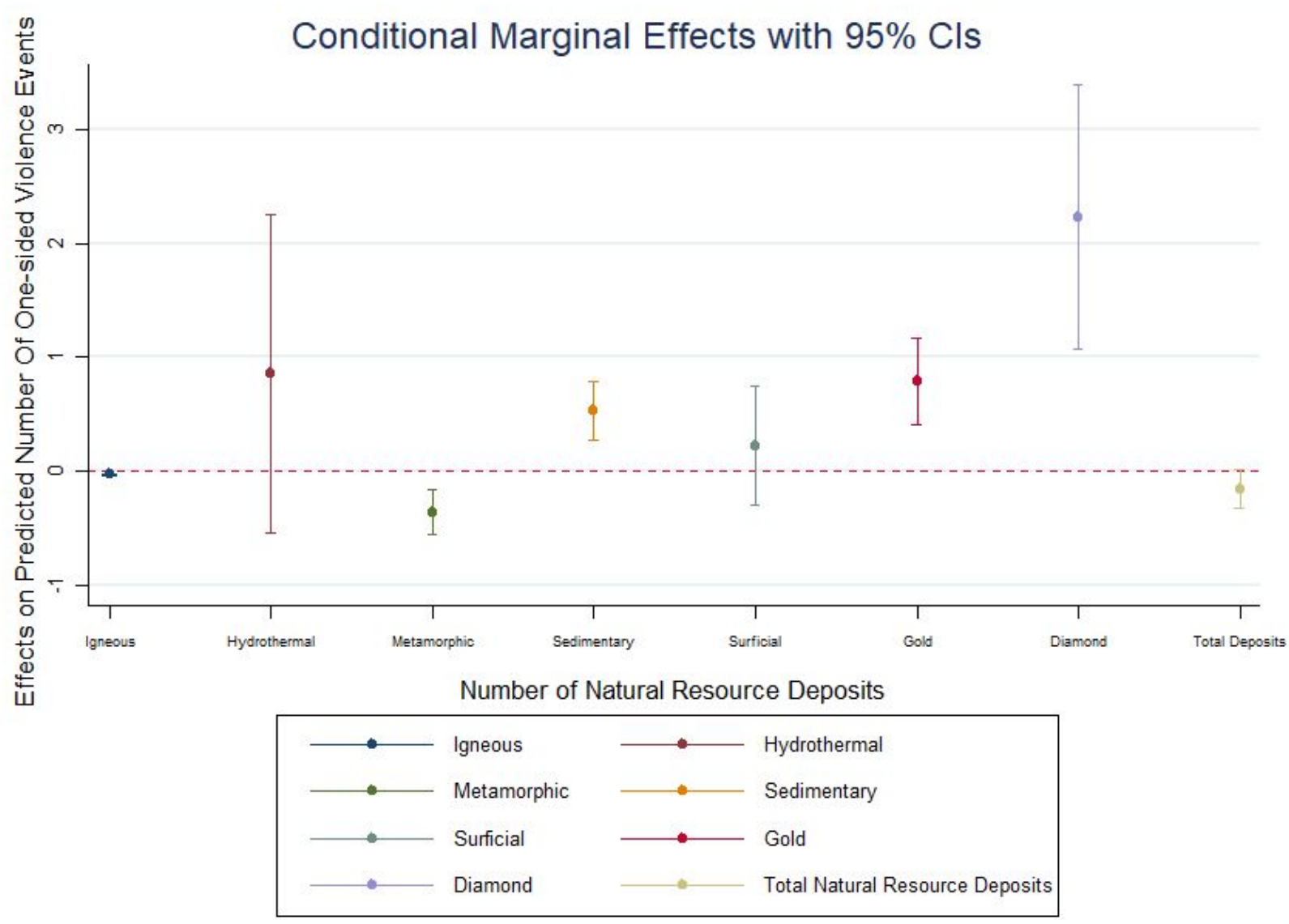

Figure 2: Conditional marginal effects on the predicted number of one-sided conflict events by resource type and the total number of deposits. 


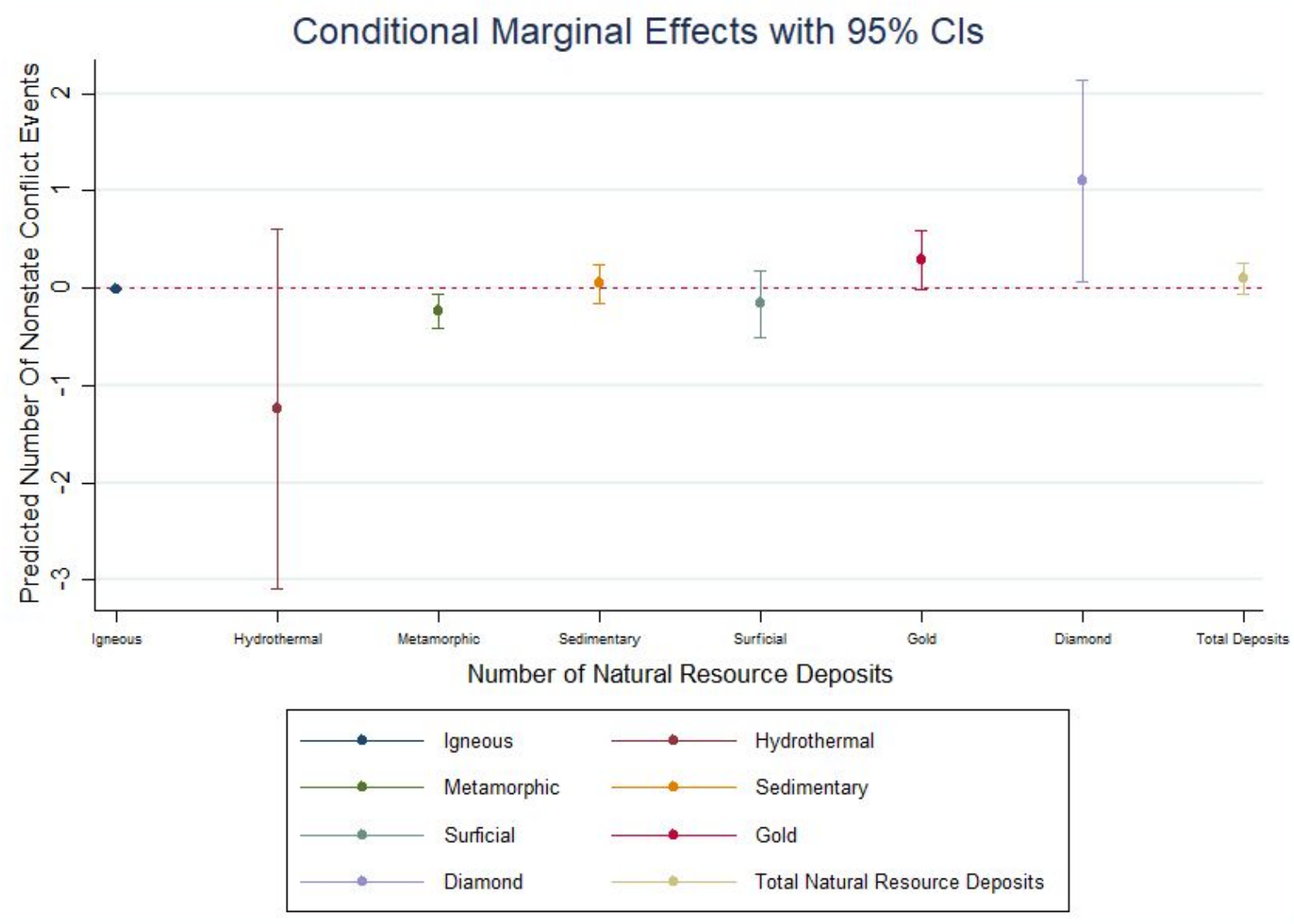

Figure 3: Conditional marginal effects on the predicted number of non-state conflict events by resource type and the total number of deposits. 


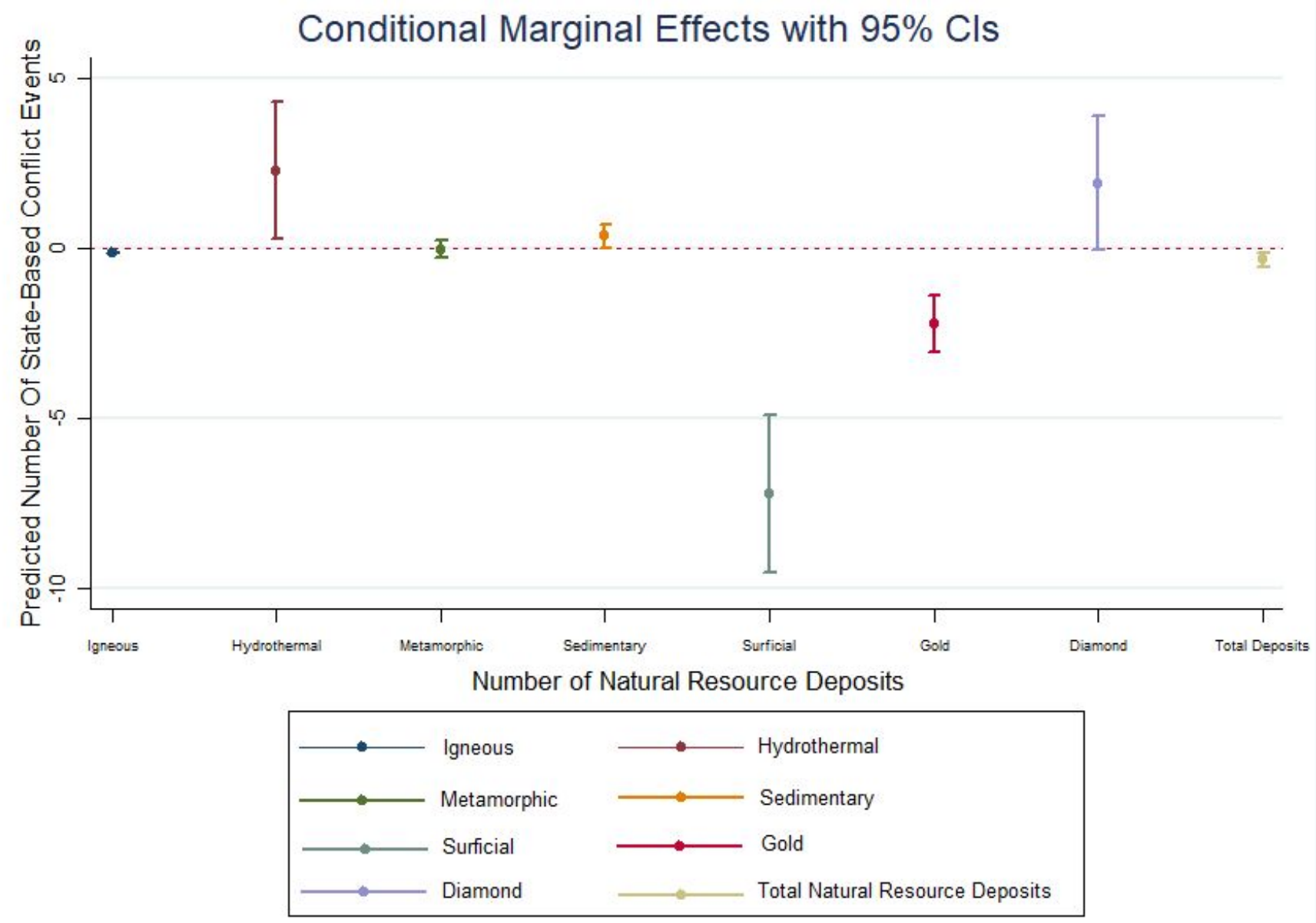

Figure 4: Conditional marginal effects on the predicted number of state-based conflict events by resource type and the total number of deposits. 
Figure 5: Conditional marginal effects on the predicted number of conflict events not targeting civilians by resource type and

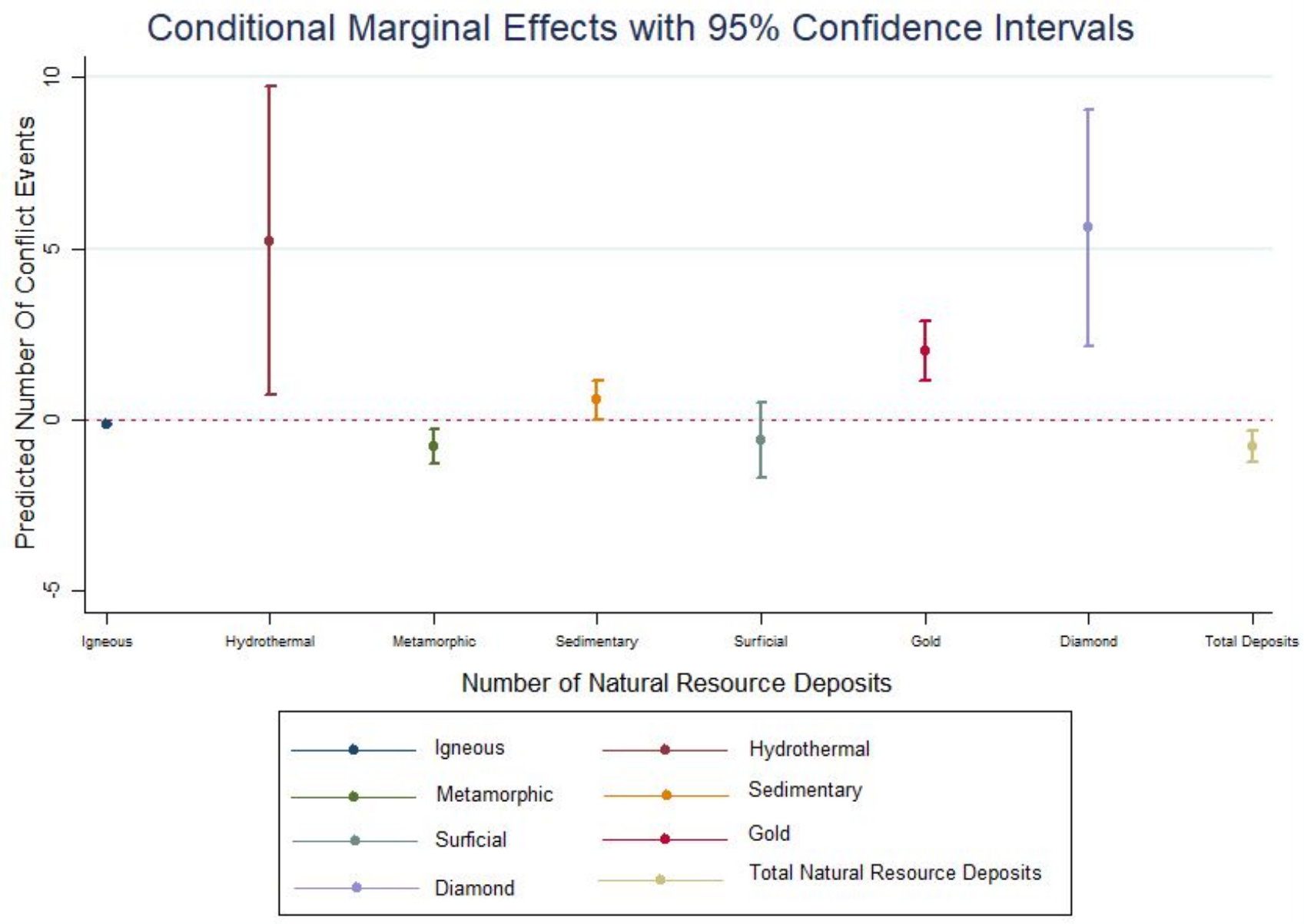

the total number of deposits.

One crucial limitation to mention here is the lack of time-related data incorporated into the analyses. Although I am able to correlate the location of different natural resource types and occurrences of civil conflict, the static data discussed here does not show how incidents of conflict and the knowledge or production status of different natural resources varies over time. Future iterations of the dataset will incorporate temporal data.

\section{The Democratic Republic of the Congo Case}

To further examine how and if the technical complexity of extraction affects the location of conflict episodes in this preliminary study, I take a closer look at the Democratic Republic of the Congo (DRC). The DRC is known for its resource wealth as well as for entrenched civil conflict. The variety of resources and types of violence is almost unparalleled, with Myanmar being a potential exception. 
As a result, the DRC makes a fitting case in which to more deeply examine the relationship between resources and conflict.

As of 2018, there were twenty-six administrative provinces in the DRC, counting Kinshasa. Of these, nine 7 are very rich in natural resources. The DRC's resource wealth includes tin, copper, coltan, diamonds, gold, manganese, lead, zinc, coal, uranium, oil, and more. Additionally, the DRC is home to lush forests that can be harvested for lumber.

Using additional natural resource data from the USGS that details the location of plants, producers, undeveloped deposits, occurrences and placers in addition to the dataset I developed for this project, I conducted an average points in polygon analysis. The average points in polygon analysis simply shows the average number of conflict incidents which took place within administrative units which shared a particular characteristic: the type of natural resource deposits they contained.

\begin{tabular}{|c|c|c|c|c|}
\hline \multicolumn{5}{|c|}{$\begin{array}{l}\text { Table 2: Average Number of Incidents of Conflict in Administrative Units } \\
\text { Containing Natural Resources of a Given Type }\end{array}$} \\
\hline & Hydrothermal & Igneous & Surficial & Sedimentary \\
\hline State-Based Conflict & 1.2 & 65.3 & 19.7 & 20 \\
\hline non-state Violence & 0.2 & 25.6 & 8 & 4 \\
\hline One-sided Violence & 0.7 & 121.4 & 32.7 & 13 \\
\hline Total Violence & 9.4 & 223.6 & 64 & 100 \\
\hline
\end{tabular}

The average points in polygons are displayed in Table 2, above. The administrative units in which the most incidents of state-based conflict, non-state violence, and one-sided violence took place were those containing igneous natural resource deposits. The second highest total incidents of violence took place in administrative units containing sedimentary deposits, which also had the second-highest number of incidents of state-based conflict. There were more incidents of non-state and one-sided violence in surficial deposits than sedimentary ones, however.

The logic of the theory proposed in this paper is partially confirmed by the average common points-in-polygon analysis results in Table 2. Although I was only able to partially address the technical complexity of natural resource extraction and could not examine human capital, the theory predicts that armed actors will be driven by the results of a cost-benefit analysis. Surficial deposits, which are simplistic to mine and require very little if any human capital or infrastructural investment, are an appealing prize but would not be worth fighting over. Sedimentary deposits require some human capital and the technical complexity they require is greater than that of surficial deposits. armed actors must be prepared to absorb a greater cost if they choose to exploit natural resources located in sedimentary deposits.

The cost for armed actors to exploit natural resources is not as high for sedimentary deposits as it is for igneous deposits. The finding regarding igneous deposits is at first confusing, therefore.

\footnotetext{
${ }^{7}$ Haut-Lomami, Tangayika, Maniema, Haut-Katanga, Ituri, Haut-Uele, Nord Kivu, Sud Kivu, and Kongo-Central
} 
However, when the context of the natural resource deposits in the Democratic Republic of the Congo is evaluated more closely, the relationship between administrative units with igneous deposits and incidents of conflict of all kinds is clarified. There are eight igneous deposits in the Democratic Republic of the Congo, but only three of these are in administrative units that do not include other types of natural resource deposits. All three of the deposits located in administrative units that do not include other natural resource deposit types are located in Nord-Kivu, an extreme outlier for violence in the Democratic Republic of the Congo, located on the border of the Democratic Republic of the Congo with Uganda and Rwanda. Nord-Kivu is home to a massive refugee population, is the main site of the Kivu conflict, and has porous international borders with states that have also experienced intrastate violence.

In Table 3 below, I include a revised average for igneous deposits that removes the Nord-Kivu administrative unit. Removing Nord-Kivu, igneous deposits no longer appear to be the most important in determining the location of conflict. Rather, as predicted by the theory discussed in this prospectus, sedimentary deposits experience the most state-based conflict and for the average total incidents of violence. Administrative units that have surficial deposits experienced more incidents of one-sided violence. More incidents of non-state violence occurred in administrative units that contain igneous deposits, however.

\begin{tabular}{|l|l|l|l|r|r|r|}
\hline \multicolumn{7}{|c|}{$\begin{array}{c}\text { Table 3: Number of Incidents of Conflict in Administrative Units } \\
\text { Containing Natural Resources of a Given Type }\end{array}$} \\
\hline & Hydrothermal & Igneous & Surficial & Sedimentary \\
\hline State-Based Conflict & 1.2 & 16.6 & 19.7 & 20 \\
\hline non-state Violence & 0.2 & 10 & 8 & 4 \\
\hline One-sided Violence & 0.7 & 20.2 & 32.7 & 13 \\
\hline Total Violence & 9.4 & 62.4 & 64 & 100 \\
\hline
\end{tabular}

The simple averages shown in Tables 2 and 3 are intriguing, but do not control for other factors that might influence the number of conflicts within a given administrative unit. They lack the ability to address the mechanism put forward in my theory, but they do suggest some support for it and suggest that more investigation into the impacts of the technical complexity of natural resource extraction and human capital is warranted.

\section{Discussion}

The characteristics of a natural resource extraction site are not limited to the type of material within which it is deposited. While this is the piece I am able to tackle prior to including expert opinion surveys, there are several other characteristics to consider when evaluating the human capital and technical capacity requirements for natural resource extraction that may affect the ability for armed actors to exploit a natural resource deposit. For example, dependency on a foreign multinational corporation for extraction may imply that a natural resource is dependent on significant 
human capital in a way that amplifies local grievances. Illegal outflows and price manipulation by multinational corporations extracting resources in Africa leads to an estimated \$62.2 billion USD loss for the continent each year. The Democratic Republic of the Congo lost an estimated minimum of $\$ 1.36$ billion USD in revenue between 2010-2012 as a result of price-gouged sales of mining assets to offshore mining corporations (Smith 2013). Many multinational extraction firms bring in human capital from their origin country to manage locally-sourced miners. For example, the Collum mine in Zambia is run by a Chinese corporation and as of 2012, the managers and supervisors at the mine were Chinese (Wonacott 2012). At the same time and as mentioned above, armed actors likely face strong incentives not to engage in attempts to control these deposits due to the presence of militarized security forces maintained by the extraction companies (Christensen 2019).

While water, fisheries, hydrocarbons, or vegetation resources are conflict-relevant natural resources whose role in conflict I believe can be explained using the logic of the theory proposed in this dissertation, I do not address them in this prospectus. Water, although ubiquitous and relatively low-value in many parts of the world is a prized resource in others. It can be difficult to extract in some regions, requiring the use of desalination plants or other purification facilities, may be used as a power source in hydroelectric dams, and can be contaminated to inflict suffering on one's enemies. Fisheries vary widely in their levels of stock and economic value, the skills and technology required to exploit them. Despite the importance of both to livelihoods and human survival, they are more frequently discussed in relation to communal and interstate conflicts, and less at the intrastate level.

Like critical and hydrothermal mineral resources, hydrocarbons and vegetation resources (e.g. timber, agricultural crops, and narcotics) vary widely in their difficulty of extraction and the technical knowledge required to exploit them. Each has theoretical ties to civil conflict that have been argued in the past, but the data regarding their geographic presence in conflict zones is more difficult to reliably obtain. Lujala et al's PETRODATA v.1.2 dataset is incomplete, although it represents a potential resource for some data on hydrocarbons (Lujala et al 2007). Massive oil discoveries since the publication of the Lujala et al (2007) dataset include deposits in the United States of America, the Gulf of Mexico, Tanzania, Canada, Egypt, Congo - Brazzaville, Nigeria, Malaysia, Angola, and Mozambique, among others (Blackmon 2019, Cohen 2018, DiLallo 2014, Egan 2017). The presence of some of these data may be important for conflict analysis post-2007, and hence need to be included before analyses of modern civil conflict can be conducted with the PETRODATA dataset. The role of vegetation resources may best be examined via case study research, as the location of these resources may shift due to conflict and to the best of my knowledge, reliable, global, consistently-coded and aggregatable data on vegetation and crop production is not available despite efforts by the Food and Agriculture Organization to catalog such data.

\section{Broader Implications and Potential Observables}

There are several broader implications of the theory I put forward in this prospectus. For example, if the human capital and technical capacity for extracting natural resources is as important as I argue, social scientists may be able to work together with mining engineers and geologists to determine more 
about where conflict is likely to take place over natural resources in an ongoing conflict, and potentially even create conflict hazard maps for ongoing conflicts.

Furthermore, if the theory behind this prospectus is confirmed, it can be extended to examine other questions in the civil conflict literature. More recently, the conversation around natural resources in conflict has shifted to include discussion of how resources are extracted and in what context. Scholars have begun to assess the impact of natural resources on rebel treatment of civilians in conflict (e.g. Weinstein 2005, 2007; Whitaker et al 2019; Wood 2010). As the importance of governance-related factors has increased in the literature, scholars have also begun to ask what institutional contexts make rebel resource extraction more likely and under what circumstances armed actors will provide public services and goods to civilians living in territory under their control (e.g. Florea FORTHCOMING, Stewart et al FORTHCOMING).

Existing research into the effects of natural resources on the treatment of civilians by armed actors is divided into several camps. Following Ross (2004), some authors suggest that natural resources can both increase conflict severity and encourage cooperation between belligerents in civil conflict. Several studies find no statistically significant relationship between the presence of lootable natural resources and the use of violence against civilians by armed actors (Wood 2010, 2014). Yet, another camp, spurred by Weinstein's $(2005,2007)$ works argues that the presence of natural resources can lead armed actors to act more violently towards civilians. In particular, terrorism and sexual violence have been indicated as more likely to be used by armed actors with access to natural resources (Fortna et al 2018, Whitaker et al 2019).

Findings regarding the use of sexual violence exhibit considerable nuance however, as groups that are extorting are mor elikely to employ sexual violence, whereas those that smuggle natural resources are less likely to use sexual violence. The authors argue that rebel group dependence on local populations for smuggling makes them less likely to use sexual violence (Whitaker et al 2019).

It is possible, therefore, that armed actors choose how to exploit natural resources based on the human capital and technical knowledge they will require to profit off of resources extraction. Stronger armed actors should be better able to control local populations and exploit human capital than weaker groups, thus they will pay less heed to human capital constraints, When technical expertise is crucial however, armed actors might be more careful about committing indiscriminate violence against local populations whose technical knowledge and expertise may be necessary for resource extraction, and may even provide public goods and services to local populations (Stewart et al FORTHCOMING).

Additionally, research into rebel governance is still in its early stages. Why and when armed actors choose to create governance institutions is a relatively new question in the literature, and more so where the role of natural resources is concerned. There are empirical inconsistencies in this nascent literature that a conceptualization of natural resources based on human capital and technical complexity requirements might resolve.

Florea (FORTHCOMING) finds that armed actors with access to natural resources are less likely to invest in governance institutions than armed actors that have access to immobile assets. Stewart et al (FORTHCOMING) however, find armed actors that exploit natural resources are more 
likely to provide health services for the population living under their control. The two findings would seem to be at odds with each other, as the provision of public goods and the creation of institutions are often thought of as similar objectives; i.e. as part of rebel state-making processes.

Where Florea (FORTHCOMING) and Stewart et al (FORTHCOMING) seem to present contradictory findings regarding the likelihood that rebel actors will provide public goods and services, I argue that viewing natural resources through their human capital requirements can reconcile them. When a natural resource is human capital intense, rebel actors need to pay greater heed to the desires of the local population and foreign corporations that may be part of the extraction process. Thus, some state-building efforts may be necessary. However, a weak rebel group is unlikely to have the capacity to establish such infrastructure. Thus, we may more often observe armed actors making use of less human capital-intense natural resources.

Finally, outside the realm of civil conflict, extensions of the proposed theory may also have useful implications. The proposed theory directly addresses questions regarding the limits of rationality that affect actors in international relations and the impact of natural resources on conflict more broadly. For example, if we retain the assumption that armed rebel actors are rational actors interacting with states in an anarchic environment, it is by no means a stretch to understand the behavior of states as similarly rational. If this is true, the behavior patterns we see exhibited by armed rebel actors interacting with and fighting over natural resources should be similarly true of states. 


\section{References}

1. American Geosciences Institute (2019) Critical Minerals. American Geosciences Institute. https://www.americangeosciences.org/critical-issues/critical-minerals

2. ACLED. (2017). Armed Conflict Location \& Event Data Project (ACLED) Codebook, 2017. Armed Conflict Location \& Event Data Project (ACLED) acleddata.com

3. Auty, Richard (2001a) The Political Economy of Resource-Driven Growth. European Economic Review, 45(4): 839-846.

4. Auty, Richard (2001b) Resource Abundance and Economic Development. Oxford: Oxford University Press.

5. Bachler, Gunther; Boge, Volker, Klotzli, Stefan; Libiszewski, Stephan; and Spillman, Kurt (1996) Environmental Degradation as a Cause of War: Ecological conflicts in the third world and peaceful ways of resolving them. Zurich: Ruegger.

6. Balcells Ventura, Laia (2017) Rivalry and Revenge: The politics of violence during civil war. Cambridge: Cambridge University Press.

7. Beech, Hannah (n.d.) Battling for Blood Jade. Time. https://time.com/battling-for-blood-jade/.

8. Bellows, John and Miguel, Edward (2009) War and Local Collective Action in Sierra Leone. Journal of Public Economics, 93(11-12): 144-157.

9. Blackmon, David (2019) World's Largest Recent Offshore Oil Discovery Progresses Amid Political Tensions, Disputes. Forbes. July 29th, 2019, https://www.forbes.com/sites/davidblackmon/2019/07/29/worlds-largest-recent-offshore-oil-discove ry-progresses-amid-political-tensions-disputes/\#73570414672f.

10. Bowcott, Owen (2017) Dutch arms trafficker to Liberia given war crimes conviction. The Guardian, April 22nd, 2017, https://www.theguardian.com/law/2017/apr/22/dutch-arms-trafficker-to-liberia-guus-kouw enhoven-given-war-crimes-conviction.

11. Buhaug, Halvard and Gates, Scott (2002) The Geography of Civil War. Journal of Peace Research, 39(4): 417-433. Doi: 10.1177/0022343302039004003.

12. Buhaug, Halvard and Lujala, Paivi (2005) Accounting for Scale: Measuring Geography in Quantitative Studies of Civil War. Political Geography, 24(4): 399-418.

13. Buhaug, Halvard and Rod, Jan Ketil (2006) Local Determinants of African Civil Wars, 1970-2001. Political Geography, 25(3): 315-335.

14. Buhaug, Halvard; Gates, Scott; and Lujala, Paivi (2009) Geography, Rebel Capability, and the Duration of Civil Conflict. Journal of Conflict Resolution, 53(4): 544-569. Doi: $10.1177 / 0022002709336457$.

15. Burma News International (2019) Report Calls for Recognition of Indigenous People's Right to Control Resources. August 29th, 2019.

https://www.bnionline.net/en/news/report-calls-recognition-indigenous-peoples-right-control-resour ces.

16. Chesterman, Charles W. (1978) The Audobon Society Field Guide to North American Rocks and Minerals. New York: Knopf.

17. Christensen, Darin (2019) Concession Stands: How mining investments incite protest in Africa. International Organization, 73(1): 65-101. Doi: 10.1017/S0020818318000413. 
18. Cohen, Ariel (2018) America's Oil and Gas Reserves Double with Massive New Permian Discovery.

Forbes, (December 21, 2018).

https://www.forbes.com/sites/arielcohen/2018/12/21/americas-oil-and-gas-reserves-double-with-mas sive-new-permian-discovery/\#906c07a2c91e.

19. Collier, Paul and Hoeffler, Anke (1998) On Economic Causes of Civil War. Oxford Economic Papers, 50(4):563-573.

20. Collier, Paul and Hoeffler, Anke (2004) Greed and Grievance in Civil War. Oxford Economics Papers, 56: 563-595. Doi: 10.1093/oep/gpf064.

21. Davies, V. A. B. (2000). Sierra Leone: ironic tragedy. Journal of African Economies, 9(3), 349-369.

22. Dillabough-Lefebvre, Dominique (2019) The Wa Art of Not Being Governed. The Diplomat, (May 28th 2019), https://thediplomat.com/2019/05/the-wa-art-of-not-being-governed/

23. DiLallo, Matthew (2014) 10 Massive Oil and Gas Discoveries Made in 2013. The Motley Fool, (January 13, 2014).

https://www.fool.com/investing/general/2014/01/13/10-massive-oil-and-gas-discoveries-made-in-201 3.aspx.

24. Dube, Oeindrila and Vargas, Juan F. (2013) Commodity Price Shocks and Civil Conflict: Evidence from Colombia. Review of Economic Studies, 80: 1384-1421. Doi: 10.1093/restud/rdt009.

25. Egan, Matt (2017) Massive oil discovery in Alaska is biggest onshore find in 30 years. CNN Business, (March 10, 2017). https://money.cnn.com/2017/03/10/investing/alaska-oil-discovery-repsol-spain/.

26. Elbadawi, Ibrahaim and Sambanis, Nicholas (2002) How Much War Will We See? Explaining the prevalence of civil war. Journal of Conflict Resolution, 46(3): 307-334.

https://doi.org/10.1177/0022002702046003001.

27. Elfversson, Emma (2019) How Government Bias Can Fuel Communal Conflicts in Africa. The Conversation, August 18th, 2019. http://theconversation.com/how-government-bias-can-fuel-communal-conflicts-in-africa-121640.

28. el-Gamaty, Guma (2019) The Battle for Libya’s Oil Wealth is Set to Intensify. Middle East Eye, June 5th, 2019. https://www.middleeasteye.net/opinion/battle-libyas-oil-wealth-set-intensify.

29. Enough Project (2018) Progress and Challenges on Conflict Minerals: Facts on Dodd-Frank 1502. (June 2018) https://enoughproject.org/wp-content/uploads/Progress-and-challenges-June-2018.pdf

30. Fairhead, James (2001) "9: International Dimensions of Conflict over Natural and Environmental Resources" in Violent Environments (Nancy Lee Peluso and Michael Watts ed.s). Ithaca, NY: Cornell University Press.

31. Florea, Adrian (FORTHCOMING) Rebel Governance in De Facto States. Ostrom Workshop Paper currently under review for publication. https://ostromworkshop.indiana.edu/pdf/pelio-working-group/florea-paper.pdf

32. Flynn, Daniel (2014) Insight - Gold, diamonds feed Central African religious violence. Reuters World News, (July 29th 2014).

https://www.reuters.com/article/uk-centralafrica-resources-insight/insight-gold-diamonds-feed-centra l-african-religious-violence-idUKKBNOFY0LT20140729.

33. Fortna, Virginia Page; Lotito, Nicholas J.; and Rubin, Michael A. (2018) Don't Bite the Hand that Feeds: Rebel Funding Sources and the Use of Terrorism in Civil Wars. International Studies Quarterly, 62: 782-794. Doi: 10.1093/isq/sqy038. 
34. France24 (2019) Yemen Houthi drones hit major Saudi oil sites, sources say supplies disrupted. France 24, (September 14, 2019). https://www.france24.com/en/20190914-drone-attacks-cause-fires-two-saudi-aramco-oil-facilities.

35. Gemological Institute of America (2019) Tanzanite Journey. https://www.gia.edu/tanzanite-journey.

36. George and Bennett (2005)

37. Gerring, John (2008) Case Selection for Case-Study Analysis: Qualitative and quantitative techniques. The Oxford Handbook of Political Methodology. Box-Steffensmeier, Janet M.; Brady, Henry E.; and Collier, David. Doi: 10.1093/oxfordhb/9780199286546.003.0028.

38. Gilmore, Elisabeth; Gleditsch, Nils Petter, Lujala, Päivi, and Rød, Jan Ketil (2005) Conflict Diamonds: A New Dataset. Conflict Management and Peace Science, 22(3): 257-292.

39. Hammond, Jesse (2018) Maps of Mayhem: Strategic location and deadly violence in civil war. Journal of Peace Research, 55(1): 32-46. Doi: 10.1177/0022343317702956.

40. Handloff, R. E., Roberts, T. D. \& Library Of Congress Federal Research Division (1991) Cote d'Ivoire: a country study. Washington, D.C.: Federal Research Division, Library of Congress: For sale by the Supt. of Docs., U.S. G.P.O. [Pdf] Retrieved from the Library of Congress, https://www.loc.gov/item/90005878/.

41. Hazen, Jennifer M. (2013) What Rebels Want: Resources and supply networks in wartime. Ithaca: Cornell University Press.

42. Hinkkainen, K. H. and Kreutz, J. (2018) Natural Resource Wars in the Shadow of the Future: Explaining spatial dynamics of violence during civil war. Journal of Peace Research. White Rose Research Online URL: http://eprints.whiterose.ac.uk/134526/.

43. Hogan, Libby. (2018) 'Slow Genocide': Myanmar's invisble war on the Kachin Christian minority. The Guardian, May 23rd, 2018. https://www.theguardian.com/world/2018/may/14/slow-genocide-myanmars-invisible-war-on-the-ka chin-christian-minority

44. Högbladh, Stina (2019) UCDP GED Codebook version 19.1. Department of Peace and Conflict Research, Uppsala University.

45. Homer-Dixon, Thomas F. (1994) Environmental Scarcities and Violent Conflict: Evidence from cases. International Security, 19(1): 5-40.

46. Homer-Dixon, Thomas F. (1999) Environment, Scarcity, and Violence. Princeton NJ: Princeton University Press.

47. Humphreys, Macartan (2005) Natural Resources, Conflict, and Conflict Resolution: Uncovering the mechanisms. Journal of Conflict Resolution, 49(4): 508-537. Doi: 10.1177/00220002705277545.

48. International Gem Society (2019) Tanzanite (Zoisite) Value, Price, and Jewelry https://www.gemsociety.org/article/tanzanite-jewelry-and-gemstone-information/

49. Johnston, Patrick (2008) The Geography of Insurgent Organization and its Consequences for Civil Wars: Evidence from Liberia and Sierra Leone. Security Studies, 17: 107-137

50. Kalyvas, Stathis N. (2006) The Logic of Violence in Civil War. Cambridge, UK: Cambridge University Press.

51. Koubi, Vally; Spilker, Gabriele; Bohmelt, Tobias; and Bernauer, Thomas (2013) Do natural resources matter for interstate and intrastate armed conflict? Journal of Peace Research, 51(2): 227-243. Doi: $10.1177 / 0022343313493455$. 
52. Larson, Jennifer M. and Lewis, Janet I. (2018) Rumors, Kinship Networks, and Rebel Group Formation. International Organization, 72(4): 871-903. Doi: 10.1017/S0020818318000243.

53. LeBillon, Philippe (2001) The Political Ecology of War: Natural resources and armed conflict. Political Geography, 20(5): 561-584.

54. Lessman, Christian and Steinkraus, Arne (2019) The Geography of Natural Resources, Ethnic Inequality, and Civil Conflicts. European Journal of Political Economy, 59: 33-51. Doi: 10.1016/j.ejpoleco.2019.01.005

55. Lujala, Paivi (2009) Deadly Combat Over Natural Resources: Gems, petroleum, drugs, and the severity of armed conflict. Journal of Conflict Resolution, 53(1): 50-71.

56. Lujala, Paivi (2010) The Spoils of Nature: Armed civil conflict and rebel access to natural resources. Journal of Peace Research, 47(1): 15-28.

57. Lujala, Paivi; Gleditsch, Nils Petter; and Gilmore, Elisabeth (2005) A Diamond Curse? Civil war and a lootable resource. Journal of Conflict Resolution, 49(4): 538-562. Doi: 10.1177/00220002705277548.

58. Lujala, Päivi; Jan Ketil Rød \& Nadia Thieme, 2007. 'Fighting over Oil: Introducing A New Dataset', Conflict Management and Peace Science 24(3), 239-256.

59. Lujala, Paivi and Rustad, Siri Aas (2011) High-value Natural Resources: A blessing or a curse for peace? Sustainable Development Law \& Policy, 12(1): 19-22, 56-57.

60. Malango, Washikala (2016) Armed Groups and Mineral Extraction in the DRC. World Policy, (March 8th, 2016) https://worldpolicy.org/2016/03/08/armed-groups-and-mineral-extraction-in-the-drc/.

61. Mildner, Stormy-Annika; Lauster, Gitta; and Wodni, Wiebke (2011) Scarcity and Abundance Revisited: A literature review on natural resources and conflict. International Journal of Conflict and Violence, 5(1): 155-172.

62. Mining Technology (2018) Blessing and curse: understanding the social impact of Chinese mining in Africa. Mining Technology, (January 18th 2018) https://www.mining-technology.com/features/blessing-curse-understanding-social-impact-chinese-mi ning-africa/.

63. Mirante, Edith (2019) A Waste of Lives: The scramble for jade in Myanmar's Kachin State. Himal Southasian, August 13th, 2019.

http://himalmag.com/a-waste-of-lives-jade-mining-myanmar-labour-environment-exploitation-edithmirante-2019/

64. Nillesen, Eleonora and Bulte, Erwin (2014) Natural Resources and Violent Conflict. The Annual Review of Resource Economics, 6: 69-83. Doi: 10.1146/annurev-resource-091912-151910.

65. Olsson, Ola and Siba, Eyerusalem (2013) Ethnic Cleansing or Resource Struggle in Darfur? An empirical analysis. Journal of Development Economics, 103: 299-312. Doi: 10.1016/j.jdevco.2013.02.004.

66. Papyrakis, Elissaios (2017) The Resource Curse - What Have We Learned from Two Decades of Intensive Research: Introduction to the special issue. The Journal of Development Studies, 53(2): 175-185. Doi: 10.1080/00220388.2016.1160070.

67. Phillips-Alvarez, Laura (2019) Post-conflict Reconciliation in Sierra Leone. Borgen Magazine, November 9th, 2019. https://www.borgenmagazine.com/reconciliation-in-sierra-leone/.

68. Pwint, Nan Lwin Hnin (2018) KIA Says Tatmadaw On the Offensive to Clear Economic Corridor. The Irrawaddy, February 13th 2018. https://www.irrawaddy.com/in-person/kia-says-tatmadaw-offensive-clear-economic-corridor.html. 
69. Raleigh, Clionadh, Andrew Linke, Håvard Hegre and Joakim Karlsen. (2010). Introducing ACLED-Armed Conflict Location and Event Data. Journal of Peace Research, 47(5) 651-660.

70. Regan, Patrick M. and Norton, Daniel (2005) Greed, Grievance, and Mobilization in Civil Wars. Journal of Conflict Resolution, 49(3): 319-336.

71. Rettberg, Angelika and Ortiz-Riomalo, Juan Felipe (2016) Golden Opportunity, or a New Twist on the Resource-Conflict Relationship: Links Between the Drug Trade and Illegal Gold Mining in Colombia. World Development, 84(C): 82-96. Doi: 10.1016/j.worlddev.2016.03.020.

72. Ross, Michael L. (2003) Oil, Drugs, and Diamonds: The varying roles of natural resources in civil war. In The Political Economy of Armed Conflict, (K. Ballentine and J. Sherman, ed.s), pp. 47-72. Boulder, CO: Lynne Rienner.

73. Ross, Michael L. (2004) How Do Natural Resources Influence Civil War? Evidence from Thirteen Cases. International Organization, 58(1): 35-67. Doi: 10.1017/S0002081830458102X.

74. Ross, Michael L. (2004) What do we know about natural resources and civil war? Journal of Peace Research. 41:337-56.

75. Ross, Michael L. (2006) A Closer Look at Oil, Diamonds, and Civil War. Annu. Rev. Polit. Sci. 2006. 9:265-300. doi: 10.1146/annurev.polisci.9.081304.161338.

76. Ross, Michael L. (2012) The Oil Curse: How petroleum wealth shapes the development of nations. Princeton NJ: Princeton University Press.

77. Samset, Ingrid (2009) Natural Resource Wealth, Conflict, and Peacebuilding. Report in External Series. New York: Program on States and Security, Graduate Center, City University of New York (Synthesis Series).

78. Smith, David (2013) Africa 'ripped off big time by foreign resource firms, says bank chief. The Guardian, (June 18th, 2013). https://www.theguardian.com/global-development/2013/jun/18/africa-ripped-off-foreign-resource-fi $\underline{\mathrm{rms}}$

79. Sorens, Jason (2011) Mineral production, territory, and ethnic rebellion: The role of rebel constituencies. Journal of Peace Research, 48(5): 571-585.

80. Stanton, Jessica A. (2016) Violence and Restraint in Civil War. Cambridge UK: Cambridge University Press.

81. Sundberg, Ralph and Melander, Erik (2013) Introducing the UCDP Georeferenced Event Dataset. Journal of Peace Research, 50(4): 523-532. Doi: 10.1177/0022343313484347.

82. Stewart, Megan; Conrad, Justin; and Reyes-Reardon, Liana (FORTHCOMING) Revisiting Opportunism in Civil Conflict: Natural resource extraction and healthcare provision. Under review/forthcoming at American Political Science Review.

83. Tarrow, Sydney (2015) War and Social Movements. Emerging Trends in the Social and Behavioral Sciences. Wiley Online Library. https://doi.org/10.1002/9781118900772.etrds0381.

84. Tollefsen, Andreas Forø, Strand, Håvard and Buhaug, Halvard (2012) PRIO-GRID: A unified spatial data structure. Journal of Peace Research 49(2): 363-374

85. USGS (2019) USGS Mineral Resources Online Spatial Data. United States Geological Survey. https://mrdata.usgs.gov/.

86. Vlaskamp, Martijn (2019) First, Do No Harm: Five questions the EU needs to keep in mind for a sensitive approach to conflict resources. CIDOB Notes Internacionales, 219: https://www.cidob.org/en/publications/publication_series/notes_internacionals/n1_219/first_do_n 
o harm five questions the eu needs to keep in mind for a sensitive approach to conflict res ources.

87. Weinstein, Jeremy (2005) Resources and the Information Problem in Rebel Recruitment. Journal of Conflict Resolution, 49(4): 598-624. Doi: 10.1177/0022002705277802.

88. Weinstein, Jeremy (2007)Inside Rebellion: The Politics of Insurgent Violence. New York: Cambridge University Press.

89. Welsch, Heinz (2008) Resource Abundance and Internal Armed Conflict: Types of natural resources and the incidence of "new wars". Ecological Economics, 67: 503-513.

90. Whitaker, Beth Elise; Walsh, James Igoe; and Conrad, Justin (2019) Natural Resource Exploitation and Sexual Violence by Rebel Groups. The Journal of Politics, 81(2): 702-706. http://dx.doi.org/10.1086/701637.

91. Wonacott, Paul (2012). China investment brings jobs, conflict to zambia mines. Wall Street Journal (Online) (September 5th, 2012). Retrieved from https://colorado.idm.oclc.org/login?url=https://search-proquest-com.colorado.idm.oclc.org/docview /1037996936? accountid=14503.

92. Wood, Reed M. (2010) Rebel Capability and Strategic Violence Against Civilians. Journal of Peace Research, 47(5): 601-614. Doi: 10.11770022343310376473.

93. Wood, Reed M. (2014) Opportunities to Kill or Incentives for Restraint? Rebel capabilities, the origins of support, and civilian victimization in civil war. Conflict Management and Peace Science, 31(5): 461-480. Doi: 10.2307/26271374.

94. Wright, J. B. (1985) Geology and Mineral Resources of West Africa. London UK: Springer. 10.1007/978-94-015-3932-6. 


\section{Appendix: \\ Resource Location Maps}




\section{Critical Minerals}

The America

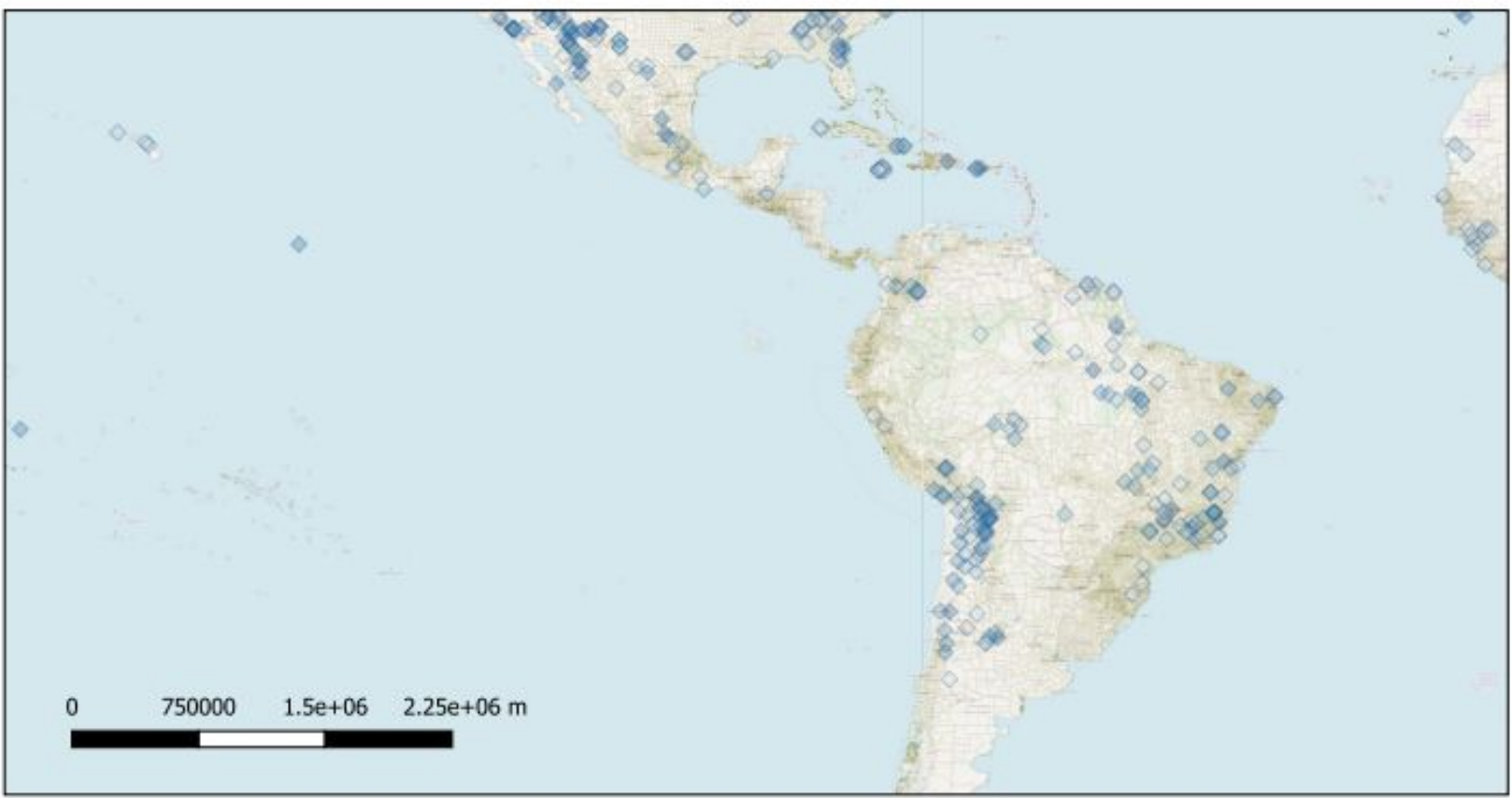

Figure B1. The map above shows the location of critical mineral deposits (blue diamonds) in the Americas, excluding Canada and the United States.

\section{Surficial and Sedimentary Deposits}

The America

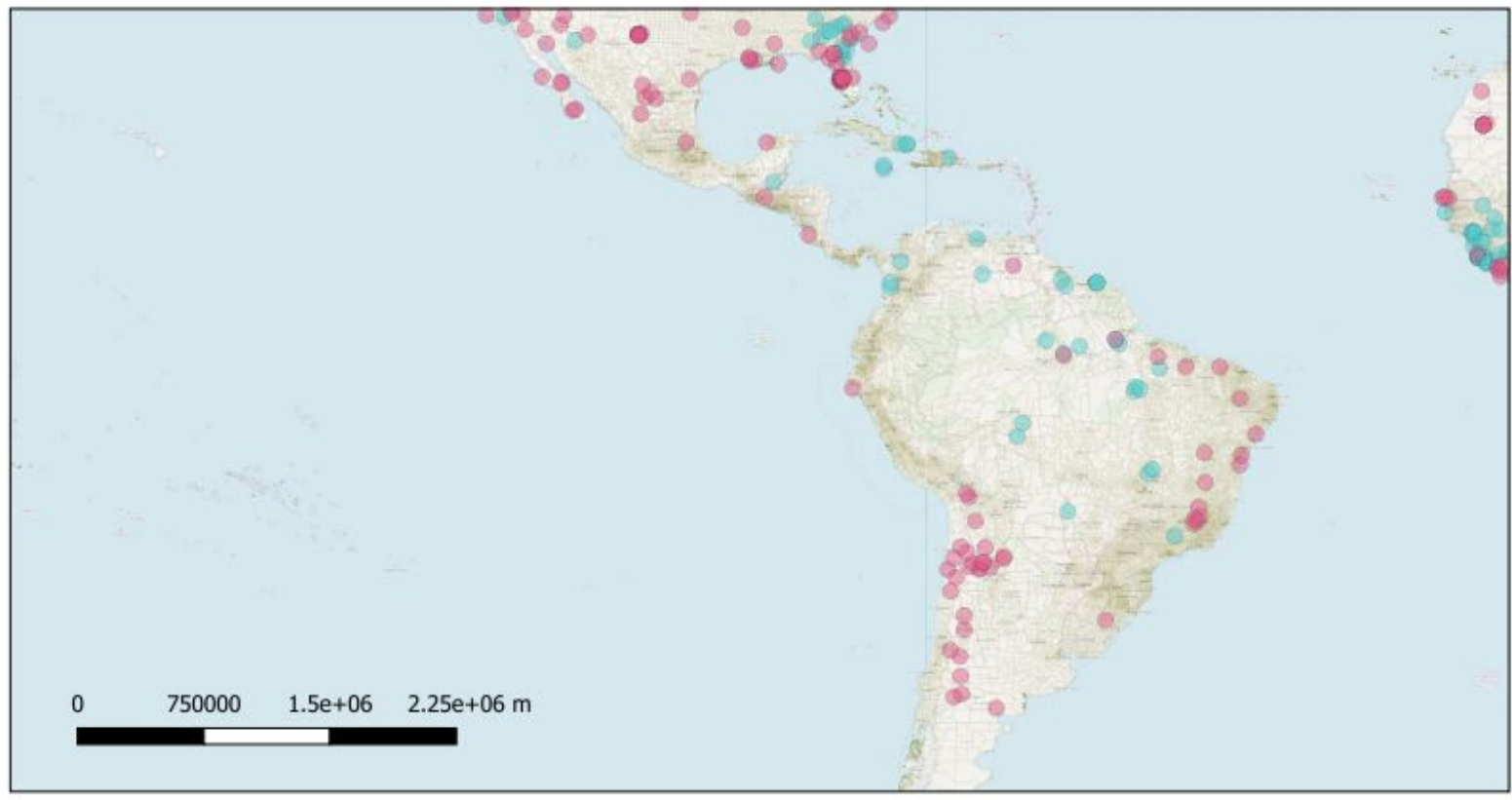

Figure B2. The map above shows the location of surficial (aquamarine circles) and sedimentary (pink circles) mineral deposits in the Americas, excluding Canada and the United States. 


\section{Igneous and Metamorphic Deposits}

The America

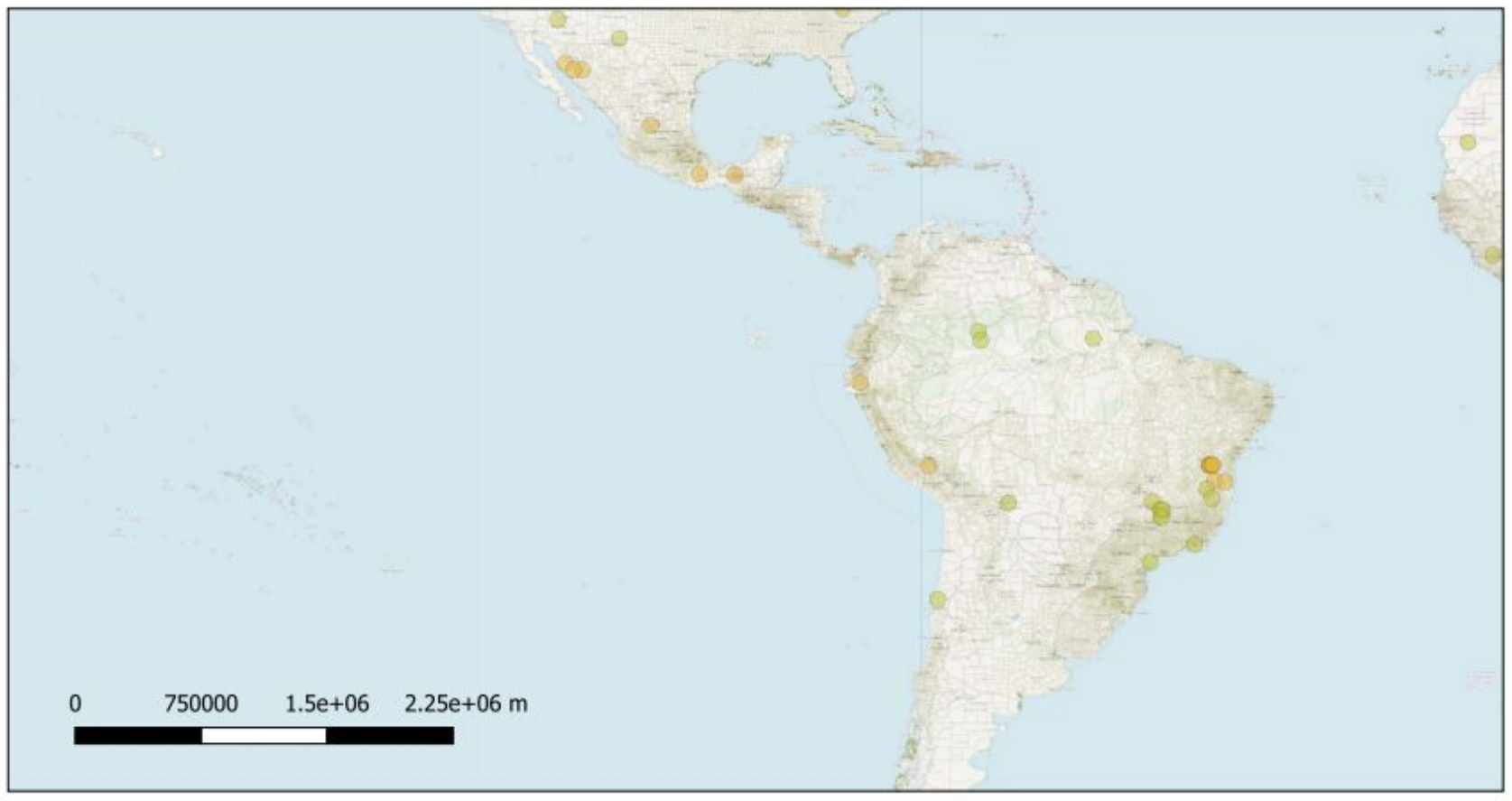

Figure B3. The map above shows the location of igneous (green circles) and metamorphic (orange circles) mineral deposits in the Americas, excluding Canada and the United States.

\section{Gemstone and Hydrothermal Deposits}

The America

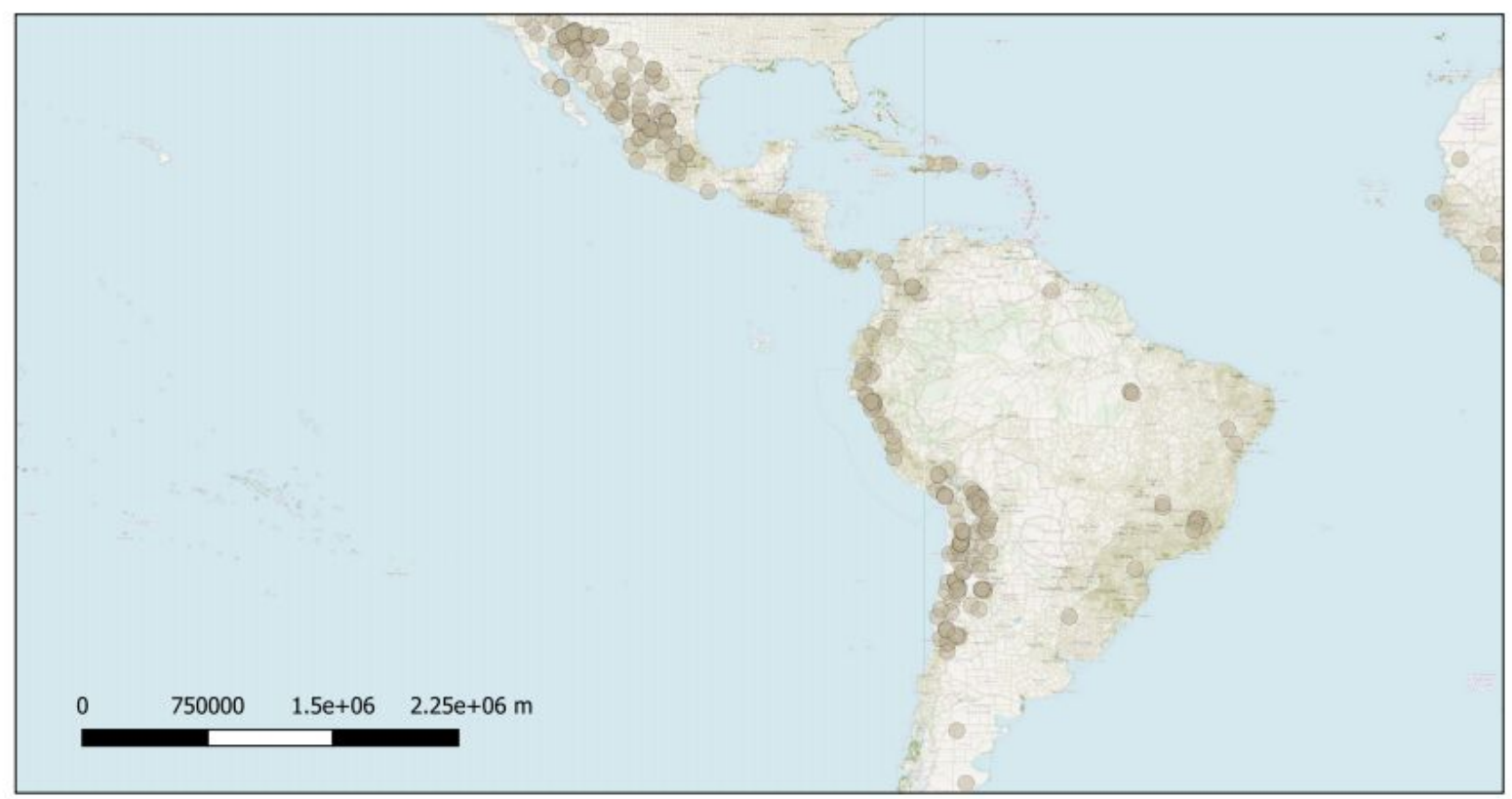

Figure B4. The map above shows the location of gemstone (pink circles) and hydrothermal (gray circles) mineral deposits in the Americas, excluding Canada and the United States. 


\section{Critical Minerals}

Europe, Africa, and Asia

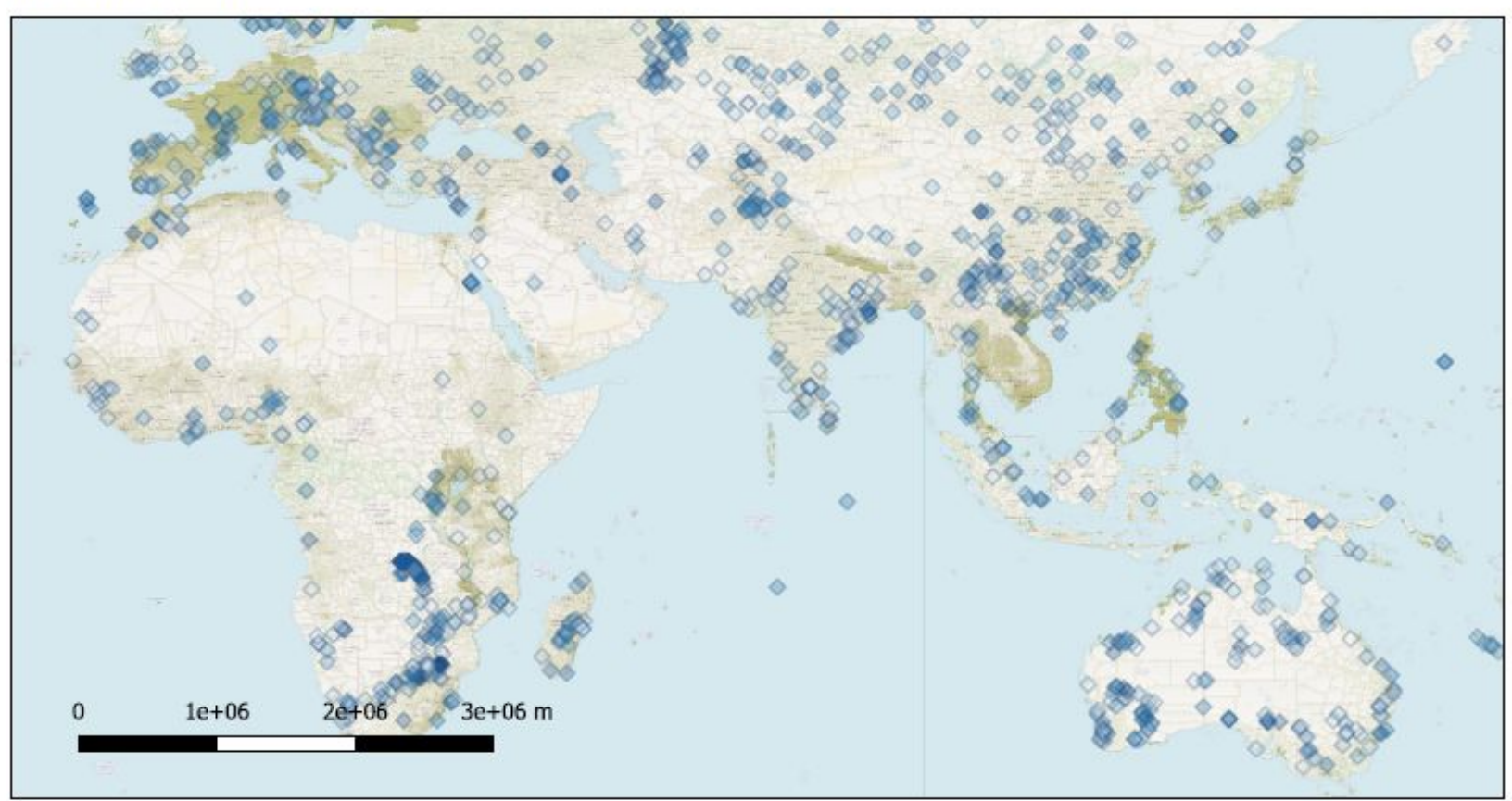

Figure B5. The map above shows the locations of critical mineral deposits (blue diamonds) in Europe, Africa, and Asia.

\section{Gemstone and Hydrothermal Deposits}

Europe, Africa, and Asia

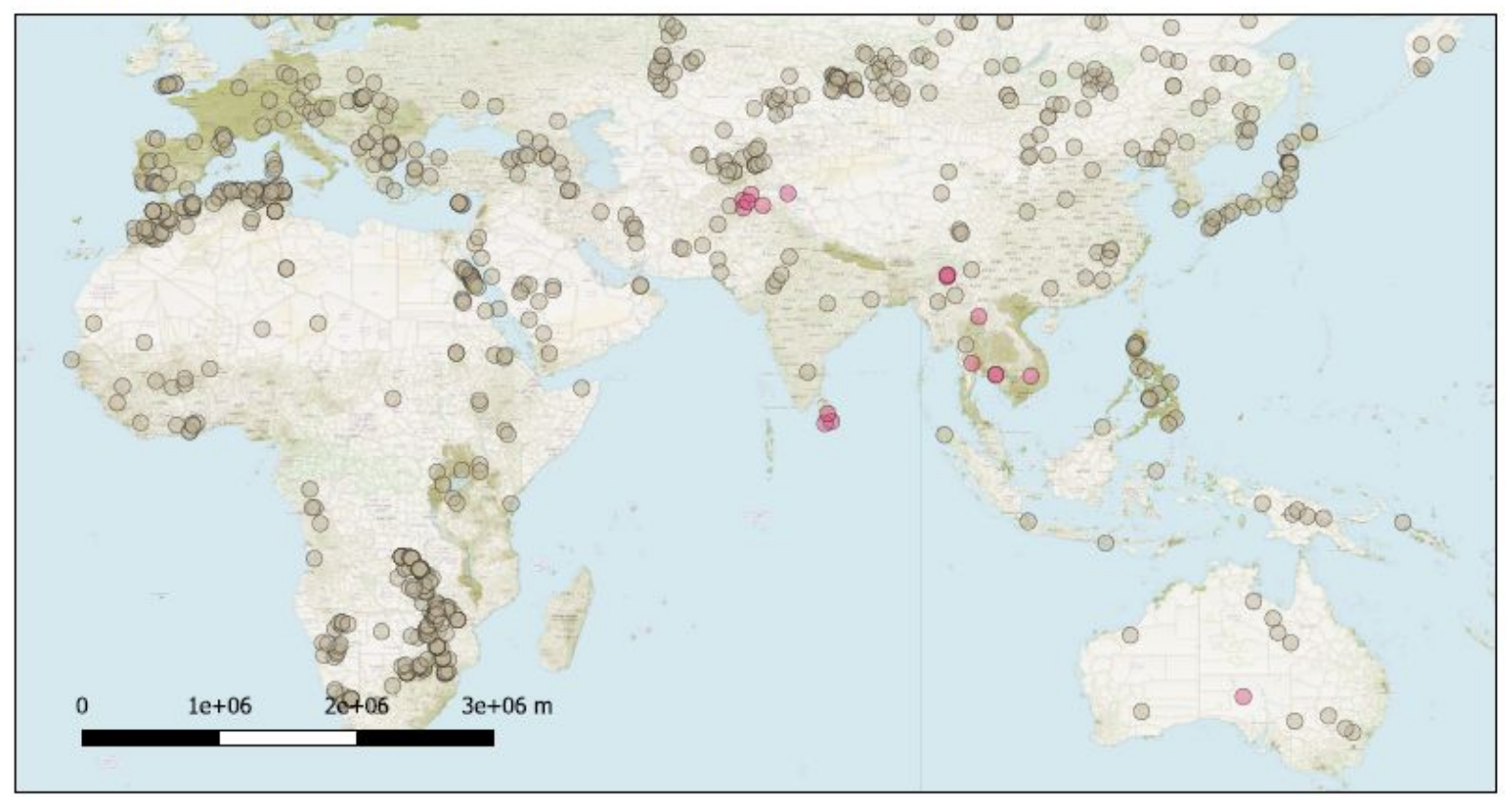

Figure B6. The map above shows the locations of gemstone (pink circles) and hydrothermal (gray circles) deposits in Europe, Africa, and Asia. 


\section{Igneous and Metamorphic Deposits}

Europe, Africa, and Asia

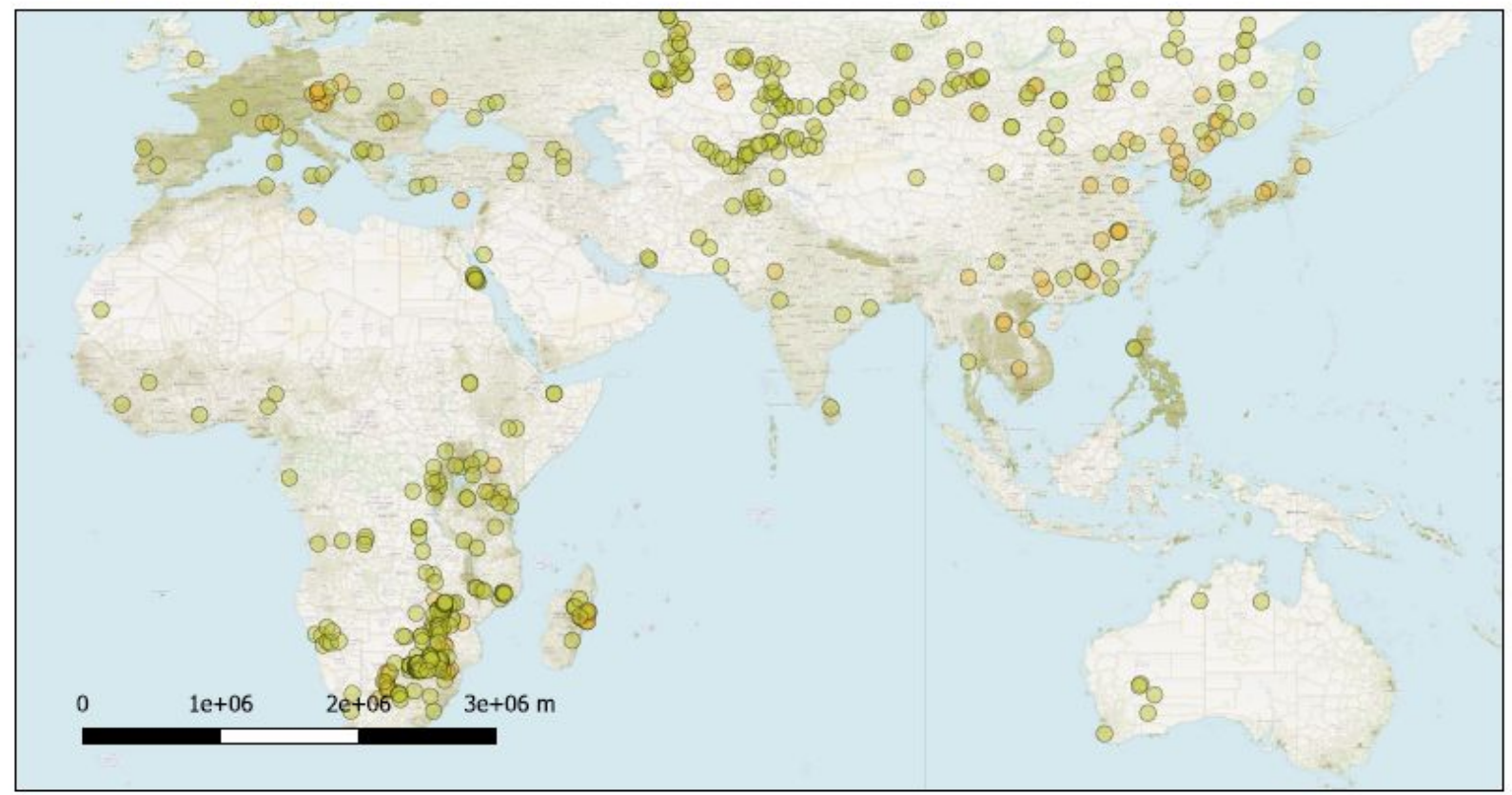

Figure B7. The above map shows the locations of igneous (green circles) and metamorphic (orange circles) deposits in Europe, Asia, and Africa.

\section{Surficial and Sedimentary Deposits}

Europe, Africa, and Asia

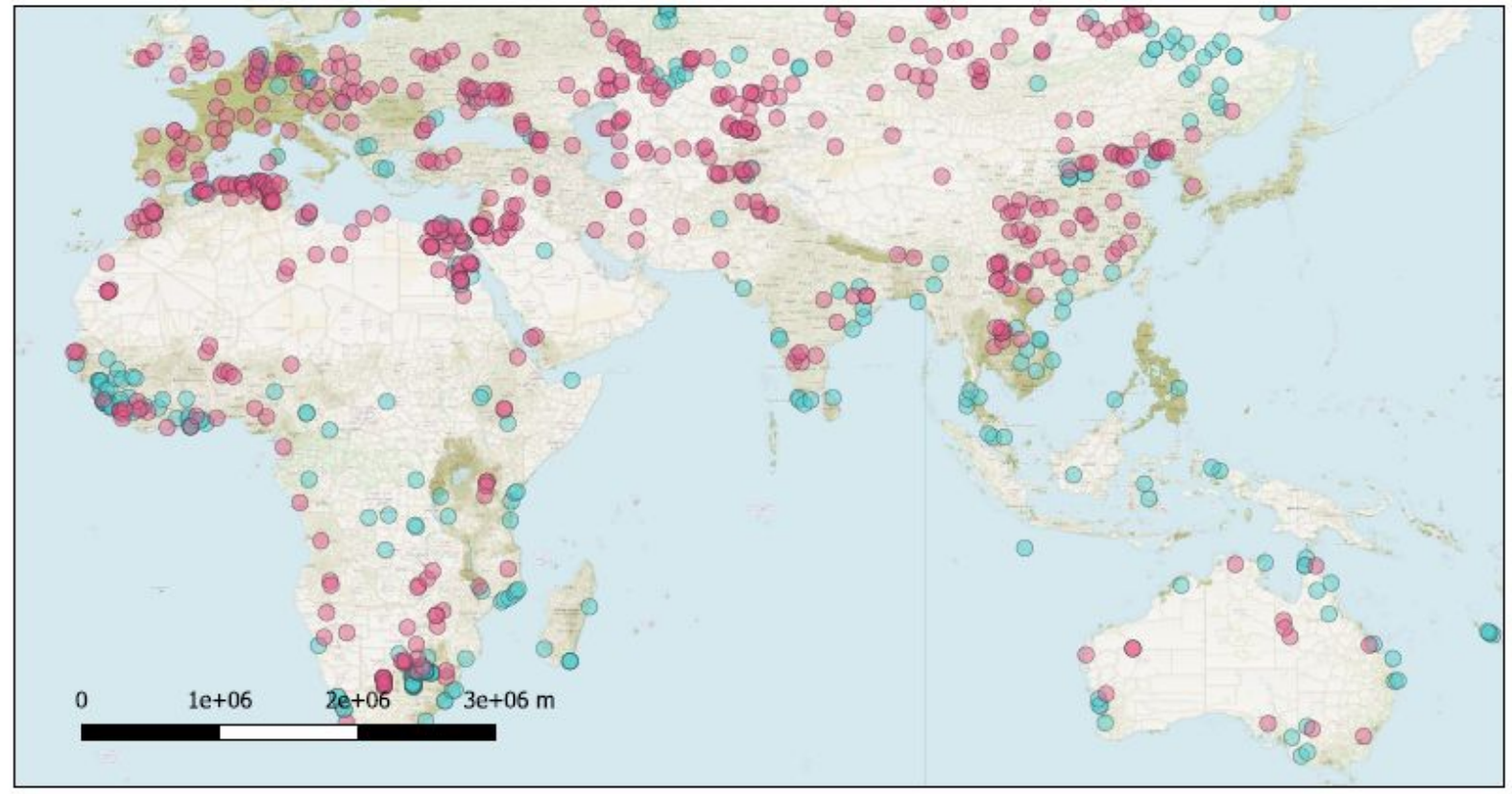

Figure B8. The above map shows the locations of surficial (aquamarine circles) and sedimentary (magenta circles) deposits in Europe, Asia, and Africa. 